\title{
Mind the Gap \\ The Difference between U.S. and European Loan Rates
}

Berg, Tobias; Saunders, Anthony; Steffen, Sascha; Streitz, Daniel

Document Version

Accepted author manuscript

Published in:

The Review of Financial Studies

DOI:

$10.1093 /$ rfs/hhw097

Publication date:

2017

License

Unspecified

Citation for published version (APA):

Berg, T., Saunders, A., Steffen, S., \& Streitz, D. (2017). Mind the Gap: The Difference between U.S. and

European Loan Rates. The Review of Financial Studies, 30(3), 948-987. https://doi.org/10.1093/rfs/hhw097

Link to publication in CBS Research Portal

\section{General rights}

Copyright and moral rights for the publications made accessible in the public portal are retained by the authors and/or other copyright owners and it is a condition of accessing publications that users recognise and abide by the legal requirements associated with these rights.

Take down policy

If you believe that this document breaches copyright please contact us (research.lib@cbs.dk) providing details, and we will remove access to the work immediately and investigate your claim. 


\title{
Mind the Gap: The Difference between U.S. and European Loan Rates
}

\section{Tobias Berg, Anthony Saunders, Sascha Steffen, and Daniel Streitz}

\author{
Journal article (Accepted manuscript*)
}

\section{Please cite this article as:}

Berg, T., Saunders, A., Steffen, S., \& Streitz, D. (2017). Mind the Gap: The Difference between U.S. and European Loan Rates. The Review of Financial Studies, 3a3), 948-987. https://doi.org/10.1093/rfs/hhw097

This is a pre-copyedited, author-produced version of an article accepted for publication in The Review of Financial Studies following peer review. The version of record is available online at:

\section{DOI: https://doi.org/10.1093/rfs/hhw097}

\footnotetext{
* This version of the article has been accepted for publication and undergone full peer review but has not been through the copyediting, typesetting, pagination and proofreading process, which may lead to differences between this version and the publisher's final version AKA Version of Record.
} 


\title{
Review of Financial Studies, forthcoming
}

\author{
Mind the Gap: The Difference between \\ U.S. and European Loan Rates
}

\section{Tobias Berg $^{\dagger}$ Anthony Saunders ${ }^{\ddagger}$ Sascha Steffen $^{*} \quad$ Daniel Streitz $^{*}$}

July 2016

\begin{abstract}
We analyze pricing differences between U.S. and European syndicated loans over the 19922014 period. We explicitly distinguish credit lines from term loans. For credit lines, U.S. borrowers pay significantly higher spreads, but lower fees, resulting in similar total costs of borrowing in both markets. Credit line usage is more cyclical in the U.S., which provides a rationale for the pricing structure difference. For term loans, we analyze the channels of the cross-country loan price differential and document the importance of: the composition of term loan borrowers and the loan supply by institutional investors and foreign banks.
\end{abstract}

JEL-Classification: G30, G20, G15

Keywords: Loans, corporate debt, fees, market integration, globalization

The authors would like to thank Tim Adam, Mark Carey, Greg Nini, Krista Schwarz, Alex Stomper, and seminar participants at Cambridge, Humboldt University, University of Cologne, University of Bonn, and the 2015 FIRS Annual Meeting for helpful comments and suggestions. Furthermore, we thank the Editor, Phil Strahan, and two anonymous referees for their comments and suggestions.

${ }^{\dagger}$ Frankfurt School of Finance \& Management, Sonnemannallee 9-11, 60314 Frankfurt, Germany, Email: t.berg@fs.de. Tel: +49 69 154008-515.

${ }^{\ddagger}$ Stern School of Business, New York University, 44 West 4th Street, New York, USA, Email: asaunder@stern.nyu.edu Tel: +1 2129980711.

*University of Mannheim and Centre for European Economic Research (ZEW). L 7, 1, 68161

Mannheim, Germany, Email: steffen@zew.de, Tel: +49 621 1235-140.

¥ E.CA Economics, Schlossplatz 1, 10178 Berlin, Germany, Email: streitz@e-ca.com, Tel: +49 30 212317091 


\section{Introduction}

In this paper, we analyze pricing differences between the U.S. and the European syndicated loan market. Looking at pricing differences across markets is important as it helps us understand international financial market integration as well as prevalent differences in pricing structures and composition of firms that are active in these markets. For example, Carey and Nini (2007) showed that average spreads for syndicated loans differed systematically between the European and the U.S. market. Loan spreads in the corporate syndicated loan market were, on average, about 30 basis points (bps) smaller in Europe during the 1992 to 2002 period. This finding is puzzling as financial theory suggests that arbitrage opportunities should be competed away unless it is prevented by market frictions. However, the market for syndicated loans is globally integrated with a large number of international participants (borrowers, banks, and non-bank lenders). Thus, it is not surprising that this pricing puzzle has stirred a wide debate among academics. In this paper, we revisit the pricing puzzle documented by Carey and Nini (2007), henceforth CN, and offer new perspectives on this pricing "gap".

We start by reproducing the result from $\mathrm{CN}$ over the same sample period used in their paper (1992-2002) and the same single statistic to measure a firm's borrowing costs (i.e., the All-In-Spread-Drawn (AISD)). We replicate their result, finding both a similar economic and statistical magnitude of the gap as CN. We then extend the sample to the 1992-2014 period to address the following research questions: Does the pricing gap exist across the different pricing dimensions in loan contracts and for different loan types? And, does the pricing gap persist over time, as financial markets have become more innovative and global, attracting a large number of (non-bank) institutional investors? How has an elevated institutional loan supply as well as loan supply by foreign lenders affected loan pricing and importantly the pricing differences between U.S. and European loans? These important questions are the ones we seek to answer in this paper. 
Pricing mechanisms differ between credit lines and term loans and we therefore explicitly distinguish between term loans (approximately 30\% of the Dealscan sample) and lines of credit (approximately $70 \%$ of the Dealscan sample) in the remaining part of the paper. We document that the pricing puzzle is lower for lines of credit (11 bps lower AISD for European borrowers) than for term loans (49 bps lower AISD for European borrowers). We extend the original CN sample (1992-2002) and include the pre-crisis period (2003-2007), the financial crisis period (2008-2010) and the European Sovereign debt crisis period (20112014). Several interesting results emerge. The pricing puzzle for credit lines is rather stable in all subperiods until 2010. In contrast, the term loan pricing difference is highly volatile, fluctuating from a 49 bps lower AISD for European borrowers in the 1992-2002 period, a 5 bps higher AISD for European borrowers in the 2003-2007 period, a 54 bps lower AISD for European borrowers in the 2008-2010 period, to a 65 bps higher AISD for European borrowers in the 2011-2014 period. Pricing mechanisms thus differ between credit lines and term loans and we analyze both loan types separately.

For lines of credit, we document that European borrowers pay a lower AISD compared to U.S. borrowers (as shown by $\mathrm{CN}$ ), however, they pay a significantly higher All-In-SpreadUndrawn (AISU). We show that even under conservative assumptions for the loan drawdown rate, the total costs of borrowing (TCB) does not differ significantly across the two markets. This result highlights the importance of fees in syndicated loan contracts (Berg, Saunders, and Steffen (2016), henceforth BSS (2016)). ${ }^{1}$ Overall, our results suggest that there is no pricing puzzle for lines of credit lines, but the pricing structure of lines of credit differs fundamentally between European and U.S. syndicated loans.

Why are the pricing structures different in U.S. and European loan markets? We find that while average draw-down rates are similar in the U.S. and Europe, U.S. firms draw down

\footnotetext{
${ }^{1}$ The total cost of borrowing is a new cost measure developed in BSS (2016) that differentiates between loan types, comprises various fees and accounts for different draw-down rates of credit lines. We explain this measure in detail in Appendix B.II.
} 
their credit lines much more in bad times when either market sources of funding dry up or when firms are doing poorly. Therefore, the sensitivity of usage rates to performance is much higher in the U.S. compared with Europe. A contract with a high AISD and a low AISU, the "U.S.-type" contract, provides disincentives for the firm to draw down a credit line. Our results are thus consistent with the idea that U.S. lenders shield themselves from draw-downs in bad times and they do so by increasing the gap between drawn and undrawn costs of credit lines.

In the next step, we analyze various channels through which differences in U.S. and European term loan spreads can be explained. Specifically, those channels include 1) the composition of term loan borrowers; and two supply-side channels, namely 2a) institutional loan supply, and 2b) cross-border activity / loan supply by foreign banks. To the best of our knowledge, this is the first paper that analyzes the role of these alternative channels in the relative pricing of syndicated loans across different countries.

For term loans, credit ratings at the time of issuance provide an imperfect measure of risk. Term loan issuers are more likely to be downgraded than upgraded, so the average term loan issuer is riskier than the observed credit rating at issuance. ${ }^{2}$ This effect is stronger in the U.S. than in Europe: ratings of U.S. firms which obtain a term loan decline, on average by 0.5 notches more in the first year after loan origination, compared to European term loan issuers. These results are consistent with the narrative that firms with declining creditworthiness are unable to obtain bond funding, but rather have to rely on monitoring-intensive bank loans. Consistent with Europe being a bank-based market, this effect is significantly stronger in the U.S. than it is in Europe. This narrative is supported by the fact that we do not find a similar effect for credit lines. In contrast to the term funding market - where firms can choose

\footnotetext{
${ }^{2}$ Given the extensive evidence on the predictability of agencies' credit rating changes (Altman and Kao (1998); Delianedis and Geske (1999); Norden and Weber (2004); Löffler (2005)), it seems reasonable to assume that these rating changes are anticipated by lenders.
} 
between issuing a corporate bond and obtaining a bank loan - credit lines are almost exclusively provided by banks (Kashyap, Rajan, and Stein (2002)).

A second channel that can help to explain term loan pricing differences between the U.S. and the European market is the supply of capital by institutional investors. The role of institutional loan supply in the U.S. market, from 2001 until the start of the financial crisis in 2008, has already been documented in the literature. Shivdasani and Wang (2011), for example, show that supply of capital from CLO funds decrease the spreads of leveraged buyout (LBO) loans as well as reduce the use of covenants, while increasing the availability of debt financing. Similarly, Ivashina and Sun (2011) show that institutional demand pressure (i.e., an increase in the supply of debt financing by institutional investors) reduced spreads on (term) loans below spreads demanded by banks for loans to otherwise identical firms. We also observe a substantial increase in U.S. institutional term loan issuances after 2001. The European loan market, on the other hand, largely lacked this increase in institutional loan suppliers. We hypothesize and empirically test whether this additional loan supply from institutional investors reduced the spreads of U.S. vis-à-vis European loans and whether the pricing gap for term loans was removed or reduced. In particular, we find that pricing differences disappeared in times of relatively high institutional loan supply in the U.S. Furthermore, the results are more pronounced for junk rated issuers, that is, the segment of the market where institutional investors are most active.

A third and final channel relates to the role of cross-border activity and foreign bank loan supply. Carey and Nini (2007) provide some evidence that cross border activity is limited over the 1992-2002 period. We document that cross-border activity in the syndicated loan market has significantly increased over time, particularly with respect to foreign banks supplying loans in the U.S. market. Our results suggest that foreign bank supply is highly correlated with the pricing differential between the U.S. and European markets - in particular for investment grade borrowers. 
Overall, these results suggest that variations in the pricing difference between the U.S. and European term loans are accompanied by variation in institutional investor flows in the below investment grade market, and by foreign bank lending flows in the investment grade market.

Our paper relates to different strands of the existing literature: first, our paper emphasizes the importance of explicitly distinguishing between different types of loans (term loans and lines of credit) when analyzing loan pricing. Gatev and Strahan (2009) show that term loans and lines of credit differ in their syndicate structure: while commercial banks dominate lending for lines of credit, investment banks, insurance companies, and hedge funds dominate for term lending. BSS (2016) document that the pricing structure of term loans and lines of credit differ significantly reflecting the various options embedded in these contracts. We also contribute to the loan contracting literature by analyzing pricing structures in an international setting and by showing that pricing structure differences can explain the loan spread differences or gap between U.S. and European syndicated loans for credit lines. Furthermore, we document that these differences in pricing structures are consistent with differences in borrower draw-down behavior in the two markets. We thereby add to the literature on the liquidity risk faced by banks stemming from their exposure to undrawn loan commitments (Cornett et al. (2011); Gatev and Strahan (2006); Gatev, Schuermann, and Strahan (2009)).

In addition, we add to the literature on the choice between private and public debt. While contingent liquidity is almost exclusively provided by banks via credit lines, term funding can also be obtained in the bond market (Gatev and Strahan (2009); Kashyap, Rajan, and Stein (2002)). ${ }^{3}$ We document that both in Europe and the U.S., companies across the credit spectrum obtain credit lines. In Europe, however, both high and low quality firms obtain term loans, while in the U.S. high quality firms are more likely to issue public debt (De

\footnotetext{
3 See also Denis and Mihov (2003), Hoshi, Kashyap, and Scharfstein (1993), Houston and James (1996), and Carey, Post, and Sharpe (1998) on the choice between public and private debt.
} 
Fiore and Uhlig (2011)). Our results indicate that European term loan issuers are not directly comparable to U.S. term loan issuers - even after controlling for observable differences in credit risk. Further, by documenting that the structure of the U.S. term loan market differs significantly from that of the European market, we add to the growing literature on the international syndicated loan market structure (Esty and Megginson (2004); Giannetti and Laeven (2012); Giannetti and Yafeh (2012)).

The paper proceeds as follows. In section 2, we discuss the institutional environment and framework. In Section 3, we describe the data, provide descriptive statistics and show basic regression results following the $\mathrm{CN}$ specification. We investigate the loan pricing puzzle separately for credit lines (Section 4) and term loans (Section 5). Section 6 concludes.

\section{Institutional Environment and Framework}

We first review the theoretical and empirical literature on loan contracting to provide an economic framework in which we can interpret our empirical results on the U.S. vs. European loan pricing puzzle. We focus on three aspects in particular, i.e., 1) the conceptual differences between credit lines and term loans; 2) for credit lines, an economic framework for credit line usage; and 3) for term funding, the choice firms have to borrow from banks or corporate bond markets.

\subsection{Credit Lines versus Term Loans}

Credit line and term loan contracts are inherently different, however, most of the empirical literature lumps them together. ${ }^{4}$ Term loans have an overall plain structure: firms receive the full loan amount upfront and repay the loan at maturity, usually 5 to 8 years after loan origination ("bullet repayment"). They pay contractually set spreads and fees until the loan

\footnotetext{
${ }^{4}$ An exception being Gatev and Strahan (2009) as noted earlier as well as BSS (2016) who empirically show how the pricing structure reflects the complexity of loan contracting.
} 
matures. Some term loans (sometimes referred to as "Term Loan A") are amortizing loans, where borrowers pay interest and principal as scheduled until maturity.

Credit lines are not only more frequently used in corporate finance, but are also more complex..$^{5}$ Instead of outright funding, credit lines provide contingent liquidity. That is, instead of drawing down the committed loan amount, firms keep the credit line as insurance against future liquidity needs (for example, as a backup for a commercial paper program). This complexity is also reflected in the pricing structure of credit lines which consists of various fees in addition to the loan spread.

Fees perform certain pricing functions and are therefore important. First, they account for options embedded in credit lines, such as the option to draw-down the credit line when firms need liquidity (Thakor, Hong, and Greenbaum (1981); Thakor (1982); Ho and Saunders (1983); Boot, Thakor and Udell (1987); Thakor and Udell (1987); Chateau (1990); Shockley and Thakor (1997)). Second, they help banks screen borrowers if the latter have private information about their own creditworthiness (Thakor and Udell (1987)). Indeed, BSS (2016) show empirically how and why fees come in various forms in loan contracts and how they vary across different loan contracts based on borrower fundamentals.

To summarize, lenders do not use a single statistic such as the interest rate spread to ensure an appropriate expected return on a loan but rather a combination of fees and spread. It is thus a testable hypothesis as to whether the observed pricing differential between U.S. loans and European loans over the 1992-2002 period was a function of the full pricing menu of loan contracts as well as the type of loan considered, and not just a function of a simple loan interest rate spread. In particular, as fees are more important for credit lines than term loans, we expect so see a larger effect of fees in the pricing for credit lines.

\footnotetext{
${ }^{5}$ Sufi (2009) reports that $82 \%$ of firm-years in the U.S. and even $32 \%$ of otherwise all-equity financed firms have credit lines.
} 


\subsection{Credit lines: Conceptual Determinants of Credit Line Usage}

Credit lines provide an option for the borrower to draw on in a situation of liquidity constraints. Therefore, borrowers are more likely to draw down a credit line if the credit line spread is favorable relative to the market spread ((BSS (2016)). In particular, firms tend to draw funds from credit lines either when market sources of funding dry up or because they are faced with a cash shortage idiosyncratically. In other words, they draw down credit lines when it is especially costly for the bank to fund them. ${ }^{6}$ To mitigate this risk, banks may increase the AISD and decrease the AISU - which provides disincentives for a firm to draw down a credit line (BSS (2016)).

Increasing the AISD and decreasing the AISU is tantamount to reducing the supply of insurance. In an influential paper, Kashyap, Rajan, and Stein (2002) argue that banks have a comparative advantage in bearing liquidity risk. Instead of reducing the supply of credit in response to more liquidity risk (by increasing the AISD), we might therefore expect banks to increase the price of insurance (by raising AISU). Importantly, however, the model by Kashyap, Rajan, and Stein (2002) does not incorporate the risk of runs on credit lines: Ivashina and Scharfstein (2010) document a significant increase in credit line draw-downs after the collapse of Lehman Brothers - with many of these draw-downs undertaken by low credit quality firms. Increasing the gap between drawn and undrawn costs of credit lines (high AISD, low AISU) is therefore one possible strategy by lenders to shield themselves from draw-downs in bad times. ${ }^{7}$

\footnotetext{
${ }^{6}$ Cornett et al. (2011) document that a significant degree of liquidity risk in banks stems from their exposure to undrawn loan commitments. Gatev and Strahan (2006) and Gatev, Schuermann, and Strahan (2009) provide evidence that inflows seeking investment in safe (secured) deposits can provide a (partial) hedge from this exposure, thus giving banks a comparative advantage over non-banks in providing credit lines.

${ }^{7}$ More generally, it is well known that insurance contracts in incomplete markets usually do not specify a price at which customers can buy full insurance but instead consist of both a price and a quantity (Rothschild and Stiglitz, 1976). For example, asymmetric information might require lenders to restrict the quantity of liquidity insurance. Similarly, lenders might restrict the quantity of liquidity insurance to provide appropriate incentives to the borrowers, for example to avoid illiquidity-seeking by firms (Acharya et al., 2014). Contracts that limit the quantity of insurance (high AISD, low AISU) should therefore be observed in markets with high information asymmetries and in markets where incentives cannot be managed by other means (for example, when incentives cannot be managed via a close borrower-lender relationship).
} 
Taken together credit lines are more likely to be drawn in bad times and the gap between drawn (AISD) and undrawn costs (AISU) is a key driver of a borrower's incentives to draw. It is thus a testable hypothesis whether the prizing puzzle also extends to the undrawn spread (AISU), and whether differences in the prizing puzzle for the AISD vs. AISU can be explained by differences in the draw-down behavior of U.S. vs. European companies.

\subsection{Term funding: Bank versus Bond Markets}

As described above, the term loan market differs from the market for credit lines in several ways. Most importantly, while term loans provide relatively long-term funding to borrowers, lines of credit usually provide short-term sources of contingent liquidity. While term funding is also available in the bond market, contingent liquidity is almost exclusively provided by banks (Gatev and Strahan (2009); Kashyap, Rajan, and Stein (2002)). This implies that firms seeking liquidity insurance have to enter the market for credit lines. In contrast, firms that require term funding have the option to either issue a corporate bond or obtain a term loan. Bond issues are especially attractive for large rated companies with low credit risk that do not require close monitoring by banks.

Several studies show that European countries have bank-based capital markets in that corporations obtain most of their debt financing from banks (De Fiore and Uhlig (2011); Gorton and Schmid (2000)). Figure 1 plots the debt structure of U.S. and European companies since 2002 based on data from Capital IQ. ${ }^{8}$

[Figure 1]

Figure 1 provides interesting insights into the debt structure of European and U.S. companies that are consistent with the prior literature. Panel A of Figure 1 shows that while rated European firms obtain about $45 \%$ of their debt financing via bond markets, the ratio of

\footnotetext{
${ }^{8}$ The figure is based on all public non-financial U.S. and European firms covered by Capital IQ. Before 2002 no reliable debt structure information is available. The data sample will be described in more detail in the next section. The broad pattern of differences between U.S. and European firms' debt structures is not sensitive to the sample choice.
} 
bond debt to other debt is over $75 \%$ for rated U.S. companies. Panel B of Figure 1 plots the number of loan issues by credit quality. While we observe both high and low quality term loan issuers in Europe, the vast majority of term loan issuers in the U.S. are non-investment grade firms. $^{9}$

This descriptive evidence suggests that large European companies are more likely to borrow via term loans, while large U.S. companies are more likely to satisfy their funding needs via bond issues. It is thus a testable hypothesis whether a pricing puzzle is also prevalent in the term loan market for investment grade firms, i.e., we should be more likely to observe larger low risk European companies issuing term loans than large low risk U.S. companies (who issue bonds instead).

\section{The Loan Pricing Puzzle}

\subsection{Data}

We obtain information on individual syndicated loan facilities from the Dealscan database maintained by the Loan Pricing Corporation (henceforth, LPC). LPC Dealscan contains detailed information on loans to large firms. While a large part of the literature using LPC data focuses on loans to U.S. corporations, LPC Dealscan also provides information on large non-U.S. loans. ${ }^{10}$ To investigate loan spread differences between U.S. and European loans, we extract all loan facilities issued by borrowers in the U.S. and Europe. We define European/U.S. loans based on the borrower location indicated by LPC Dealscan. ${ }^{11}$ Following

\footnotetext{
${ }^{9}$ Note that there are legal requirements to report new loan issuances in the U.S. for SEC-supervised firms. The low number of U.S. IG-rated term loans is thus unlikely due to missing information but rather reflects the decision of high quality firms to use alternative sources of funds such as bonds. While there is no legal requirement to report new loan issuances in Europe, the rating distribution in Dealscan reflects the rating distribution of firms in the Compustat universe.

${ }^{10}$ See for instance, Giannetti and Laeven (2012), Giannetti and Yafeh (2012). Saunders and Steffen (2011) use Dealscan data to investigate loan spread differences between public and private firms in the UK.

${ }^{11}$ Instead of using the borrower location, one could use the market where a loan is syndicated, the currency, or the location of the majority of the lead arrangers involved in a syndicated loan. All definitions are highly correlated and our main results are robust to using any of these alternative definitions.
} 
$\mathrm{CN}$, we exclude all loans issued by borrowers that are not rated at the time of the loan issue.

Credit ratings are obtained from Standard and Poor's. Consistent with CN, we retain financial firms in our sample, however, all our results remain qualitatively unaffected if we exclude firms with SIC codes $6000-6999 .^{12}$

Our sample period covers the 1992 to 2014 period, i.e., we include both the global financial crisis and the European sovereign debt crisis. While the main focus of this paper is to understand the loan pricing puzzle, we also try to explore how both crises affected the loan cost differential for U.S. versus European firms.

We follow $\mathrm{CN}$ and do not control for borrower characteristics other than credit rating in our main analyses to avoid losing a significant number of observations (particularly for the European subsample). However, additionally we obtain borrower information from Compustat for robustness. ${ }^{13}$ All variables are described in detail in Appendix A.

Our final sample consists of 17,717 U.S. and 1,735 European loan tranches issued by 2,824 distinct borrowers (of which 370 are European firms). Table 1 presents descriptive statistics for the final sample, segregated into loans issued by U.S. and European borrowers. All values are winsorized at the $1 \%$ and $99 \%$ levels.

\section{[Table 1]}

Panel A of Table 1 shows loan characteristics. The AISD differs significantly between both markets and the median spread is 35 bps lower for European loans. Strikingly and consistent with $\mathrm{CN}$, European loans are much larger than U.S. loans. The mean/median loan amount is $\$ 588 / \$ 300$ million for U.S. loans and $\$ 985 / \$ 548$ million for European loans. Loans to European corporations also have a longer maturity compared to loans to U.S. corporations - the average maturity is 48 (57) months for U.S. (European) loans. Further, the fraction of

\footnotetext{
12 The results are available upon request.

${ }^{13}$ We use Michael Robert's Dealscan-Compustat Linking Database to merge Dealscan with Compustat (see Chava and Roberts (2008)). We obtain borrower information from the last available fiscal year before the loan issue. All our results are qualitatively similar if we control for items such as total assets, leverage, profitability, and the market-to-book ratio. The results are available upon request.
} 
credit lines is higher in the U.S. market (67\%) than in the European market (41\%). Panel B of Table 1 shows borrower characteristics. Consistent with $\mathrm{CN}$, we find that the fraction of borrowers that have an investment grade rating is larger in the European loan sample than in the U.S. sample with $68 \%$ of the borrowers having an investment grade rating at the time of the loan issue in the European market compared to $51 \%$ in the U.S. market.

\subsection{Base Specification}

To examine loan spread differences between U.S. and European corporations we first estimate a model similar to the main specification in $\mathrm{CN}$ as a benchmark model and restrict the time period to 1992 to 2002 . The regression model takes the following form.

$$
\begin{aligned}
& A I S D=\beta_{0}+\beta_{1} \text { Europe }(0 / 1)+\sum_{i} \beta_{i} \text { BorrowerCharateristic }_{i} \\
& +\sum_{j} \beta_{j} \text { LoanCharateristic }_{j}+\sum_{k} \beta_{k}{\text { FixedEffec } t_{k}}
\end{aligned}
$$

The AISD is the spread over LIBOR. We follow $\mathrm{CN}$ and do not control for borrower characteristics other than credit rating categories (dummies for each notch) in our main analysis to avoid losing a significant number of observations. Importantly, our results are qualitatively similar if we follow the robustness tests in $\mathrm{CN}$ and control for items such as total assets, leverage, profitability, and the market-to-book ratio. ${ }^{14}$

Loan characteristics include the natural logarithm of the loan amount in USD, an indicator variable for secured loans and dummy variables for different loan maturities (1-3 years, 3-6 years, >6 years, and $<1$ year (which is the omitted category)). ${ }^{15}$ Further included are loan type dummies (term loan, bridge loan, unknown, and line of credit (the omitted category)), loan purpose dummies (takeover and recapitalization finance, loans financing

\footnotetext{
${ }^{14}$ The results are available on request.

${ }^{15}$ Note that, in contrast to $\mathrm{CN}$, we do not include rating migration indicators to avoid further restricting the sample.
} 
ships, aircraft, and special-purpose vehicles, project finance, commercial paper backups, and general corporate purpose loans (the omitted category)), year dummies, and industry fixed effects (based on 2-digit SIC codes). We report the results in Panel A of Table 2.

[Table 2]

We find that the AISD is $21 \mathrm{bps}$ lower in Europe compared to the U.S. over the 1992 to 2002 period (column (1)). The magnitude of the effect is similar to the results reported by CN (25bps for the 1992 to 1998 period and 37bps for the 1999 to 2002 period, see CN Table VII column (A)). As expected, larger loans have lower spreads while secured loans have higher spreads on average. Loans with a maturity greater than 6 years have higher spreads than shortterm loans, i.e., loans with maturities below one year. The other maturity indicators are not statistically significant.

We then distinguish between investment grade (column (2)) and non-investment grade loans (column (3)). The pricing puzzle is broadly similar for both categories in terms of economic magnitude (23bps for investment-grade loans versus $31 \mathrm{bps}$ for non-investment grade loans), but the statistical significance is higher for investment grade borrowers.

We then distinguish between credit lines (column (4)) and term loans (column (5)) and find that the loan spread puzzle extends to both loan types. While credit lines of European firms have $12 \mathrm{bps}$ lower spreads than U.S. firms, the loan spread difference increases to 65bps for term loans. We test the null hypothesis that the loan cost advantage of European firms is of the same size for credit lines as term loans and reject this hypothesis at any conventional confidence level.

In a next step, we add further control variables to the $\mathrm{CN}$ specifications that have been shown to affect loan pricing (Sufi (2007) and Ivashina (2009)). In particular, we control for differences in syndicate structure using both the number of lenders and a concentration measure of the loan exposure of each syndicate member. As credit spreads (i.e., the differences between AAA and BBB yield) vary a lot over time, we also include "credit rating 
$x$ time" fixed effects. While the individual rating fixed effects account for time-invariant differences in credit risk, they also force the spreads across the credit spectrum to be constant over time. ${ }^{16}$ We report the results in Panel B of Table $2 .{ }^{17}$ Importantly, the coefficient of the Europe indicator hardly changes across these different specifications. ${ }^{18}$

We next extend the sample and include the 2003 to 2014 period and run the same specifications as in Panel B. However, we add four indicator variables characterizing loan market conditions in the different time periods. There are: "Europe 1992-2002 (0/1)" to reflect the CN period (which is always our benchmark period), "Europe 2003-2007 (0/1)" for the pre-crisis period, “Europe 2008-2010 (0/1)" for the global financial crisis period and "Europe 2011-2014 (0/1)" for the European sovereign debt crisis period. We report the results in Panel C of Table 2. Note that the coefficient of Europe 1992-2002 (0/1) is similar to Panel B.

Several interesting results emerge. First, the lower loan spreads for credit lines of European borrowers also extends to the 2003 to 2007 period. The magnitude of the difference even increases from $11 \mathrm{bps}$ to $18 \mathrm{bps}$. At the same time, however, the term loan puzzle disappears. ${ }^{19}$ This is consistent with the literature documenting a substantial increase in the supply of funds in U.S. loan markets after 2003 that lasted until the crisis started in the fall of 2007. This enhanced supply came from the entry of institutional investors into the loan syndication market, which reduced loan spreads on institutional (term) loans (Shivdasani and Wang (2011) and Ivashina and Sun (2011)).

\footnotetext{
${ }^{16}$ We thank Philip Strahan for pointing this out.

${ }^{17}$ We do not show the control variables from Panel A but refer to them as "Other Controls" going forward.

${ }^{18}$ Our results are also robust to controlling for instrumented equity volatility as suggested by Gaul and Uysal (2013). Results are available upon request.

${ }^{19}$ The number of term loan observations is significantly smaller than the number of credit line observations and hence, standard errors are higher ( 10-20 bps for the Europe (0/1) dummies in column (5) of Panel C). Estimates of pricing differences between the European and U.S. market are thus associated with larger confidence intervals for term loans. Nevertheless, differences between the Europe (0/1) dummies in column (5) of Panel C are significant at the 1 or 5 percent level, suggesting that the variation in the Europe-U.S. pricing differences over the sub-periods represents in fact changes in market conditions.
} 
Second, the term loan spread difference resurfaces in the 2008 to 2010 crisis period. In fact, the spread differences are more pronounced across all loan types and rating categories. For example, the credit line spread difference increases from 18 to $39 \mathrm{bps}$, and non-investment grade loan spreads are 71bps lower on average in Europe. Initially, the global financial crisis had arguably a larger impact on U.S. financial markets which might explain the increase in loan spreads relative to Europe.

Third, the loan spread puzzle reverses during the European sovereign debt crisis. On average, European loans carry 39bps larger spreads. During this period, loan spread differences are primarily driven by term loans, while the credit line spread differences vanishes. Both the results from the global financial crisis and the European sovereign debt crisis periods suggest that the business cycle and economic situation in the U.S. relative to Europe is an important factor in explaining the U.S.-Europe loan spread differential. ${ }^{20}$

As discussed in Section 2.1 the difference between the cost of loans in the U.S. and Europe extends beyond the simple measure of spread (AISD) and should take into account fees, especially in considering the cost of credit lines. Indeed, there are fundamental contractual differences between the spread and fee structure of credit lines and term loans. We therefore analyze credit lines (Section 4) and term loans (Section 5) separately in the following two sections.

\section{Understanding the Pricing Puzzle for Credit Lines}

\subsection{Credit Lines: AISD versus AISU}

Our results so far indicate that the magnitude of the pricing puzzle for AISD differs for term loans and lines of credit. We analyze the pricing of lines of credit in more detail in this section

\footnotetext{
${ }^{20}$ A possible explanation for the increase in loan spreads for European relative to U.S. firms during the 20112014 period is a contraction in bank loan supply in Europe. The problems in the sovereign bond markets spilled over into loan markets through the banking channel. Because of a severe lack of capital particularly of peripheral banks in the Eurozone, loan spreads considerably widened for firms in these countries relative to similar firms in Germany or other core European countries (Acharya et al., 2016; Acharya and Steffen, 2016).
} 
by distinguishing between term loans and lines of credit. This is important, as term loans provide longer term funding to borrowers, while lines of credit provide short-term contingent liquidity. Contingent liquidity means that borrowers do not necessarily have to use the entire loan amount that is committed by the bank but have the option to draw down the loan. However, to date, most loan pricing studies implicitly make this assumption by solely focusing on the All-In-Spread-Drawn (AISD) as the main proxy for the price of a loan. BSS (2016) show that virtually all credit lines contain at least one fee and that fees are used to price the draw-down option. $^{21}$

We account for this pricing structure and calculate a "Usage-Weighted-Spread (UWS)" as a more comprehensive measure of credit line pricing. The UWS is a weighted average of two pricing components:

1) The AISD is the spread paid by the borrower on the used part of a loan commitment. The AISD contains the spread and the facility fee.

2) The All-In-Spread-Undrawn (AISU), i.e., the spread paid by the borrower on committed but not used part of the loan commitment. The AISU contains the commitment fee and the facility fee and can be interpreted as the price of the option to use the credit line. Commitment fees are fees paid on the unused amount of loan commitments. Facility fees are fees paid on the entire committed amount, regardless of usage. Commitment fees and facility fees are usually mutually exclusive (BSS, 2016)). ${ }^{22}$

The UWS is thus computed as shown in (1):

\footnotetext{
21 As an example, On June 16th, 2010, Meredith Corp., an American media conglomerate, entered into a USD $150 \mathrm{mn}$ credit line under which Meredith can borrow up to the committed amount over a period of 36 months. The contract specifies that Meredith pays 37.5bps annually for each dollar that is committed but not borrowed. For each dollar borrowed under the commitment, it has to pay LIBOR plus 250bps (the interest rate spread). Obviously, it is insufficient to describe the contract by simply referring to the interest rate spread.

${ }^{22}$ Facility fees are used more frequently for contracts that contain a Competitive Bid Option (CBO), see also BSS (2016). A competitive bid option allows the borrower to solicit the best bid from its syndicated group for a given borrowing. Therefore, the loan shares by the syndicate participants are backup shares in case no sufficient bids are obtained in any of these auctions. CBOs are most prevalent for U.S. investment grade credit lines. The difference between a contract with a facility fee and a contract with a commitment fee primarily affects how fees are distributed among lenders. While the spread is only split between those lenders who actually lend under the commitment, the facility fee is split pro rata among all lenders. As we are primarily interested in the cost of borrowing to the borrower, we treat facility fees and commitment fees as substitutes.
} 
PDD (Probability of draw-down) is the probability that a committed loan is actually drawn down. A PDD of one implies that the borrower borrows the entire commitment under the loan agreement while a PDD of zero implies that the borrower never actually draws down the loan commitment at all. Ideally, one should use a firm/loan specific PDD, however, this information was not readily available prior to 2002. BSS (2016) use credit line usage data from 2002 onwards from CapitalIQ to show that the credit line draw-down rate is on average $20-30 \%$ for rated U.S. firms. ${ }^{23}$ We confirm that the average credit line usage is similar for Europe and thus we use a draw-down rate of $20-30 \%$ in the following specifications.

Figure 2 shows the pricing structure across markets. We find that, while the AISD is lower in the European market, the AISU, in contrast, is significantly higher in the European market relative to the U.S. market. This implies that the overall or actual total cost of borrowing may not be different for U.S. borrowers relative to European borrowers. For example, for investment grade borrowers in Europe, the AISD for credit lines is on average 63 bps, which is approximately 19 bps lower than in the U.S. (82 bps). For the AISU, however, we observe the opposite result, i.e., the AISU in the European market is larger than the AISU in the U.S. market (21 bps versus 16 bps). For borrowers with a below investment grade rating, the AISD (AISU) for the average European borrower is $199 \mathrm{bps}$ (58 bps), the AISD (AISU) for the average U.S. borrower is $215 \mathrm{bps}$ (42 bps). ${ }^{24}$

[Figure 2 here]

In a next step, we follow BSS (2016) and calculate a second measure which is a proxy for the total cost of borrowing (TCB) of a firm. We refer to BSS (2016) and Appendix

\footnotetext{
23 See Table III in BSS (2016).

${ }^{24}$ Appendix Table B.1 provides descriptive statistics for Figure 2 and decomposes both AISD and AISU into its components.
} 
B.II for a detailed description of the TCB measure. Note that the TCB is different from UWS in two major dimensions: first, we add any further fees (such as upfront fees, cancellation fees, and utilization fees) and second we predict usage rates of credit lines using observable firm characteristics. ${ }^{25}$ In other words, the TCB is a firm-loan specific measure of the total cost of borrowing using firm-specific usage rates for credit lines.

Table 3 shows the results from multivariate regressions for the AISD, AISU, and the usage-weighted spread as defined in (1) using the same model specifications as in Panel C of Table 2. During our benchmark $\mathrm{CN}$ period (and consistent with the univariate evidence from Figure 2), the AISD is lower, but the AISU is higher for European credit lines. For the usageweighted spread, differences between U.S. and European credit lines are economically small and statistically either insignificant or marginally significant (columns (3)-(5)). For example, the coefficient for the European market dummy is only 2 bps assuming a usage rate of $25 \%$ (column (4)). The TCB measure (based on any additional fees and a firm-specific usage rate) shows very similar results.

[Table 3 here]

These results extend to the pre-crisis (2003 to 2007) period as well as the 2008 to 2010 period. During the European sovereign debt crisis, however, the credit line puzzle reverses. The average AISD difference between U.S. and European loans is economically and statistically insignificant as the average European firm paid significantly more for drawing down credit lines compared with earlier periods. At the same time, they paid a substantially higher AISU: the AISU difference between Europe and the U.S. doubles from 11 to 23bps (column (2) in Table 3). Thus, the UWS (and TCB) differences become positive, i.e.

\footnotetext{
25 Note that Dealscan is a reliable data source for the fees, i.e., correctly reports the existence and magnitude of these fees in more than $95 \%$ of the cases. BSS (2016) use a random sample of 1,000 loan contracts from the EDGAR database, report the fee information disclosed in the original loan contracts and compare these fees with information from Dealscan for the most prominent fee types such as commitment fee, facility fee, utilization fee and cancellation fee. A detailed discussion related to upfront fees is provided in BSS (2016). This fee type is usually less frequently available due to the private nature and negotiation of upfront fees. See also Appendix B for further details on the TCB calculation.
} 
European credit lines are more costly than U.S. credit lines, and the difference is both economically and statistically significant.

Figure 3 plots the AISD and TCB differential over the 1992 to 2014 period. ${ }^{26}$ The figure illustrates that the TCB is remarkably less volatile compared with the AISD before the European sovereign debt crisis. The average AISD difference jumped by more than 100bps between 2010 and 2013, when the crisis that initially affected the U.S. more relative to Europe turned into a European crisis. Around that time, the TCB difference also rose steeply: it increased from its low in 2009 by about 80bps until reaching its peak in 2013. In 2014, however, both TCB and AISD differences seem to revert again as the European crisis abates.

Overall, we provide evidence that, while the pricing structure differed between the U.S. and the European credit line markets the overall total costs of borrowing did not (at least until the 2010 - 2013 European sovereign debt crisis). This, however, raises the question as to why the pricing structures across both markets are different. We turn to this question in the next subsection.

[Figure 3 here]

\subsection{Draw-downs of credit lines: U.S. versus European firms}

Why are the pricing structures different in U.S. and European loan markets? That is, why do U.S. credit lines have a higher AISD but a lower AISU? As described in Section 2.2, firms tend to draw down credit lines when market sources of funding dry up or because they are faced with a cash shortage idiosyncratically (Gatev and Strahan (2006); Ivashina and Scharfstein (2010)). That is, firms draw down credit lines when it is especially costly for the bank to fund the credit line. If U.S. firms tend to draw down their credit line more in crisis times relative to European firms, this could explain the combination of higher AISD and lower AISU (see also BSS (2016)). We test this hypothesis in this subsection.

\footnotetext{
${ }^{26}$ The figure plots Europe (0/1) x Year dummies from a multivariate regression.
} 


\subsubsection{Credit line usage data and stock returns}

We use credit lines of U.S. and European firms from the Dealscan database over the 2000 to 2014 period and merge them with draw-down information from CapitalIQ for the five years following the loan origination date. ${ }^{27} \mathrm{We}$ start with a broad sample of rated and unrated firms and later provide results for both subsamples. We define a new variable Usage that measures the usage of a credit line at fiscal year-end as a percentage of the notional amount of the credit line at origination. Mean usage is $24 \%$ in the U.S. and $22 \%$ in Europe and in both regions usage is clustered at the low and high end of the $0-100 \%$ interval (i.e., large proportion of firms either not using their credit lines at all or heavily using their credit lines).

To operationalize our hypothesis, we construct measures related to the performance of each individual firm and the performance of the market at large. We measure the performance of firms as the realized equity return (Equity Return) over the prior 12 months and the performance of the market as the realized stock index return (Index Return) of each country over the prior 12 months. ${ }^{28}$ Finally, we construct the variable "Excess Return" as Equity Return minus Index Return to account for the relative performance of each firm to the market. $^{29}$

\subsubsection{Univariate analysis}

In a first step, we provide univariate results related to draw down behavior of U.S. versus European firms and compute average draw-down rates for both markets by equity

\footnotetext{
${ }^{27}$ CapitalIQ data on usage is only available since 2000. Using either the contractual maturity or all years after a loan origination until the sample end (2014) does not materially affect our results.

${ }^{28}$ For example, we use the S\&P 500 for U.S. firms, the DAX 30 for German firms, and the FTSE 100 for UK firms.

${ }^{29}$ Liquidity strains on the banking system could be directly measured using the LIBOR-OIS Spread or the TED Spread (see for example Cornett et al. (2011)). However, we find that the correlation between these measures and the Index Return is very high and the Index Return can therefore be seen as a proxy for liquidity strains as well. For example, the correlation between the 3-months-LIBOR/OIS-Spread and the S\&P 500 return over the prior 12 months is -0.84 over our entire sample period. We prefer using the Index Return for two reasons: first, it is easily and consistently available for all countries in our sample. Second, it allows us to decompose the performance of firms into a systematic portion and an idiosyncratic portion and analyze how draw-downs are related to each of these components.
} 
return quintiles. Panel A of Table 4 reports the results. We also compute the differences in draw-downs for each return quintile (U.S. minus European firms) in the last column as well as t-statistics to determine statistical significance levels. Similarly, we compute draw-down difference of the lowest and the highest equity return quintile for each market and report those in the last row of Table 4.

\section{[Table 4]}

Interestingly, particularly poorly performing U.S. firms (as measured by their prior 12 months equity returns) draw-down significantly more compared with their European peers. The difference is 6.7 percentage points and highly statistically significant for firms in the lowest equity return quintile. This result extends to the second lowest return quintile and is consistent with our hypothesis that U.S. firms with relatively poor performance use their credit lines more than European firms. Results are very similar if equity return deciles are determined on the combined sample of U.S. and European firms (Panel B of Table 4).

These results can either have a time-series explanation (for example, firms using their credit lines more in 2008 than in 2005) or a cross-sectional explanation (for example, poor performing firms in 2005 using their credit lines more than good performing firms in 2005). To disentangle these effects, we run a multivariate regression in Table 5.

\subsubsection{Multivariate analysis}

Since credit line usage is likely to depend on various loan-specific features as well as borrower characteristics, we use a regression model of the following form:

$$
\begin{aligned}
& \text { Usage }=\beta_{0}+\beta_{1}(\text { Europe }(0 / 1) x \operatorname{Return}(M))+\beta_{2}(U S(0 / 1) x \operatorname{Return}(M)) \\
& +\sum \beta_{i}(\text { Loan Characteristics }) \\
& +\sum \beta_{j}\left(\text { Borrower Characteristics }_{j}\right)+\sum \beta_{k}\left(\text { FixedEffects }_{k}\right) \text {. }
\end{aligned}
$$


We construct a new variable $U S(0 / 1)$ that is one if the firm is from the U.S. and interact both the Europe and U.S. indicator variables with Return $(M)$, which is a measure of firm and market performance constructed using the previous 12-month equity return. As discussed earlier, we construct three different specifications for this variable: (i) Equity Return, (ii) Index Return, and (iii) Excess Return. We then regress Usage on these variables and interaction terms and the standard set of control variables we have used in earlier tables and report the results in Table 5. Standard errors are clustered at the firm and year level following Petersen (2009) to account for both cross-sectional and time-series correlations in the error term.

\section{[Table 5]}

We perform our analysis separately for all firms (columns (1) and (2)), only rated firms (columns (3) and (4)) and only unrated firms (columns (5) and (6)). We focus on the full sample and columns (1) and (2) first. On average, usage rates do not differ between U.S. and European firms as the small and insignificant coefficient of the Europe indicator variable suggests. ${ }^{30}$ The interaction terms, however, show that usage is much more sensitive to performance in the U.S. than in Europe. A $10 \%$ lower equity return results in an 0.93 percentage point higher usage in the U.S., but only in an 0.46 percentage points higher usage in Europe (see column (1) of Table 5). Standard deviations of equity returns are almost 50\%, implying that these differences are clearly economically significant in the order of 2.5-5 percentage point credit lines usage per one standard deviation change in the equity return. In the diagnostic section at the bottom of Table 5, we perform an F-test under the null that European firms use their credit lines similarly to U.S. firms and reject this hypothesis at any conventional confidence level. Furthermore, column (2) shows that the differences in these

\footnotetext{
${ }^{30}$ In the univariate analysis (Table 4), average usage rates are higher for the U.S. than for Europe. The difference between mean usage rates disappears once we control for loan volume. This is due to the fact that European loans are much larger on average (see Table 1) and larger firms have lower draw-down rates. Differences in the cyclicality of draw-downs that we document in Table 5 are, however, not driven by loan size differences.
} 
usage-to-performance sensitivities stem from market wide returns as well as from idiosyncratic returns.

Separating the sample into rated and unrated firms shows that the basic result extends to both subsamples: U.S. firms use credit lines more when either the market or the firm idiosyncratically deteriorates. However, the analysis reveals another interesting result: unrated U.S. and European firms draw down differently after poor idiosyncratic performance $(8.8 \%$ difference in coefficients with an F-stat of 10.31), whereas rated U.S. and European firms draw down differently after the market declines $(11.7 \%$ difference in coefficients with an Fstatistic of 16.24). ${ }^{31}$

To summarize, our results suggest that the sensitivity of usage rates to performance is different in the U.S. compared with Europe. U.S firms use credit lines more when it is particularly costly for banks to fund them (when the economy is deteriorating and many firms start to draw down at once) or when firms are doing poorly. A contract with a high AISD and a low AISU - the "U.S.-type" contract - provides disincentives for the firm to draw down a credit line in bad times. Our results are thus consistent with the idea that U.S. lenders need to shield themselves from draw-downs in bad times - and they do so by increasing the gap between drawn and undrawn costs of credit lines.

While our analysis is a useful starting point in explaining the difference in drawdown behavior in the U.S. and Europe, one caveat is in order: the fact that U.S. borrowers pay a higher AISD should discourage U.S. borrowers from drawing as often as European borrowers, if all else was equal. Our line of argument relies on some unobserved differences in draw risk between U.S. and European borrowers that overcome the direct effect of a higher AISD. These unobserved differences could be institutional factors (e.g., the existence of a

\footnotetext{
${ }^{31}$ Note that the evidence is only suggestive. The standard errors of the F-statistics related to Excess Returns implies that the difference between rated and unrated firms is not statistically significant.
} 
deeper commercial paper market making drawdowns by U.S. firms more cyclical) ${ }^{32}$, or reflect a deeper firm-borrower relationship in Europe (e.g., lower asymmetric information and lower incentive conflicts between borrowers and lenders in Europe might allow European borrowers to provide a larger quantity of liquidity insurance than U.S. borrowers). ${ }^{33}$ Exploring these issues further might provide an interesting avenue for further research.

\section{The Loan Spread Differential in the Market for Term Loans}

The previous section shows that differences in the utilization of credit lines in adverse situations is an important factor in explaining structural pricing differences between U.S. and European credit lines. The market for credit lines is the most important market for financing firms in our sample and comprises about two-thirds of all loan issues.

In this section, we analyze European and U.S. borrowers in the term loan market and investigate three important channels that affect the loan pricing differential between U.S. and European term loan issues. These are: (1) composition of term loan borrowers, (2) differences in institutional investor participation, and (3) cross-border activity - i.e., the contribution of foreign banks to term loan financing.

\subsection{Composition of term loan borrowers}

A possible channel that might affect term loan spreads is the composition of term loan borrowers. Due to the existence of a deeper corporate bond market in the U.S., term loan issuers in the U.S. have different characteristics compared to European term loan borrowers. In particular, term loan borrowers in the U.S. are of a worse credit quality -

\footnotetext{
${ }^{32}$ Kacperczyk and Schnabl (2010) document that the size of the commercial paper market in January 2007 was approximately three times larger in the U.S. compared to Europe.

${ }^{33}$ Previous literature has supported the claim that the European banking system is more relationship-oriented than the U.S. banking system (Boot and Thakor (2000)). Empirical studies documenting the particular relevance of relationship banking in the European market include Elsas and Krahnen (1998), Detragiache, Garella, and Guiso (2000), and Ongena and Smith (2000).
} 
both with respect to their existing credit rating at loan origination and with respect to their future credit rating changes. It is thus a testable hypothesis whether the composition of borrowers and associated unobserved differences in credit quality drive pricing differences between U.S. and European term loans.

Figure 4 provides a univariate comparison of credit rating changes following loan issues. The figure suggests that U.S. firms perform worse than European firms following term loan issues. In particular, U.S. investment grade firms are significantly more likely than European investment grade firms to be downgraded in the year following a term loan issue. The likelihood of a downgrade by three or more notches is approximately twice as large for U.S. investment grade term loan issuers compared to European investment grade term loan issuers.

[Figure 4 here]

There is a large literature on the predictability of agencies' credit rating changes (Altman and Kao (1998); Delianedis and Geske (1999); Norden and Weber (2004); Löffler (2005)) that suggests that these rating changes are anticipated by the market. This is consistent with the narrative that firms with a sliding creditworthiness are not able to obtain bond funding, but rather need to rely on (monitoring-intensive) bank loans.

Panel A of Table 6 presents a multivariate analysis on post-issue performance. The results confirm the univariate evidence from Figure 4: European investment grade firms perform significantly better following term loan issues than U.S. investment grade firms. The change in credit rating in the year after the loan issue is 0.5 notches worse for U.S. firms relative to European firms (see column (1), $\Delta$ Rating $>0$ indicates downgrades). Results are confirmed when looking at post-issuance changes in profitability instead of post-issuance changes in credit ratings (column (2)). In contrast, we find no post-issue performance 
differences in term loans to European and U.S. non-investment grade borrowers (column (3) and (4))..$^{34}$

[Table 6 here]

Assuming perfect foresight (or rational expectations) of credit ratings and profitability changes in the year after loan issuance, we control for post-issue performance in a multivariate regression. Results are provided in Panel B of Table 6. As credit rating changes and profitability changes are highly correlated, we only report results controlling for postissuance credit rating changes. ${ }^{35}$ Column 1 (investment grade) and column 3 (junk) provide baseline results before controlling for post-issue performance. The variation in the pricing puzzle is similar for investment grade and junk issuers: European borrowers pay significantly lower term loan spreads in the 1992-2002 and the 2008-2010 period, differences are insignificant in the 2003-2007 period, and European borrowers pay higher term loan spreads in the 2011-2014 period. A negative post-issue performance ( $\Delta$ Rating $>0$ indicates downgrades) increases spreads for both junk issuers and investment grade issuers, suggesting indeed that future rating changes are anticipated by the lenders. The results further show that controlling for post-issue performance significantly reduces the pricing puzzle for investment grade borrowers by approximately 15bps until 2010 (1992-2002: -16bps, 2003-2007: -17bps, 2008-2010: -15bps). In contrast, the effects for junk borrowers are close to zero (1992-2002: 5bps, 2003-2007: +3bps, 2008-2010: -7bps). Again, the European sovereign debt crisis period is different: since European borrowers were now more likely to be downgraded, controlling for post-issuance performance does not significantly change the pricing difference for investment grade borrowers and even increases the pricing difference from 36bps to 50bps for junk borrowers.

\footnotetext{
${ }^{34}$ Furthermore, we also do not find any differences in post-issue performance between European and U.S. borrowers for credit lines - consistent with the idea that credit lines are almost exclusively provided by banks in both the (market-based) U.S. economy as well as in the (bank-based) European economy. Results are available upon request.

${ }^{35}$ Results are very similar if we also control ex-post changes in profitability.
} 
Overall, the results presented in this section clearly demonstrate that the term loan market structure in the (market-based) U.S. economy is distinct from the structure in the (bank-based) European economy in important ways. In particular, term loan issuers in the U.S. not only have lower credit ratings on average at origination, but they also exhibit a worse post-issuance credit rating and profitability performance. Thus, any comparison of term loan price or non-price terms between the U.S. and Europe needs to take these differences into account.

\subsection{Supply side determinants}

Our earlier evidence suggests that the pricing gap between term loan borrowers in the U.S. and Europe narrowed during the 2003-2007 period, returned during the 2008-2010 period and even reversed during the 2011-2014 period. A possible explanation for these results is a change in a supply of credit, for example, by institutional lenders or foreign banks, in both the U.S. and Europe. In this section, we explore these additional supply side channels that might explain loan spread differences between U.S. and European firms.

\subsubsection{Institutional lender participation}

In this subsection we investigate institutional lender (investor) participation as a second channel that might help explain the term loan spread differential. ${ }^{36}$

While the syndicated loan market used to be dominated by banks, innovations in financial markets opened the loan market for non-bank institutions as lenders. Collateralized loan obligation (CLO) funds as well as the possibility to securitize loans created additional liquidity and competition to bank funding, creating competitive downward pressure on U.S. loan spreads. The increased role of institutional investors has been well documented in the literature (Ivashina and Sun (2011); Nadauld and Weisbach (2012); Shivdasani and Wang

\footnotetext{
${ }^{36}$ In what follows the terms institutional lenders and institutional investors are synonymous.
} 
(2011)). In addition, Massoud et al. (2011) find that hedge funds were more likely to lend to highly leveraged firms where trading on private information is highly valuable.

In addition to a greater supply of funds by institutional lenders in the syndicated loan market, the development of the secondary loan market over the post 2002 period also increased the liquidity of syndicated loans. For example, Gande and Saunders (2012) document the growth of secondary market decreased borrowers' financial constraints and freed up funds for additional lending. In turn, this may have decreased the liquidity premium included in previously illiquid loan spreads.

If the downward pricing pressure was larger for U.S. relative to European loans, this can explain, in part, the reduction in the U.S.-Europe spread differential over the 2003-2007 period. Figure 5 strikingly shows the significant increase in the supply of loans by non-bank institutional lenders over this period, particularly in the U.S.

[Figure 5 here]

Panel A of Figure 5 depicts the annual "Bank Term Loan" issuance volume for the U.S. versus Europe and Panel B of Figure 5 depicts the annual "Institutional Term Loan" issuance volume. ${ }^{37}$ Panel $\mathrm{C}$ depicts the share of institutional loans as a percentage of the total term loan market in the U.S. and Europe. We observe a substantial increase in U.S. institutional term loans after 2001 with the annual issuance volume increasing from below 100 billion USD in 2001 to over 500 billion USD in 2007 as shown in Panel B of Figure 5. ${ }^{38}$ We observe a similar, however significantly less pronounced, time trend for institutional loans in Europe. While we observe a clear shift from bank to institutional lending in the U.S., bank loans continue to dominate the term loan market in Europe. We conject that the additional

\footnotetext{
37 "Bank Term Loan" is a loan type issued for banks. These loans are usually amortizing loans and the early repayment does not suited for institutional investors such as private equity funds who have a fixed duration. "Institutional Term Loan" is a loan type that usually has a bullet repayment which is better suited for institutional investors.

${ }^{38}$ Note that Figure 5 is based on the entire Dealscan database and not only our final sample of loans to rated borrowers.
} 
loan supply from institutional investors in the U.S. worked to reduce term loan spreads in the U.S. vis-à-vis Europe, eventually closing the pricing gap.

We test this conjecture over the entire 1992-2014 sample period by introducing a new variable that measures differences in institutional investor participation in the U.S. relative to Europe. "AInstitutional lending" is defined as the difference of the ratios of institutional term loan volume as percentage of total term loan volume in the U.S. versus Europe in a particular year. ${ }^{39}$ This variable is defined on the year-level. An increase in the value of this variable from one year to the next implies more institutional investor participation in the U.S. compared with Europe.

\section{[Figure 6 here]}

Figure 6, Panel A, plots AInstitutional lending against the average spread difference between European and U.S. term loans, separately for loans to investment grade and noninvestment grade firms. ${ }^{40}$ The univariate evidence suggests a positive correlation between the spread difference and AInstitutional lending for non-investment grade borrowers. That is, European loans are relatively cheaper in years where there is little institutional loan supply in the U.S. relative to Europe. The concentration of this effect in the non-investment grade subsample is consistent with previous research highlighting the importance of institutional investors in this loan segment (see for example, Ivashina and Sun (2011)).

We next turn to a multivariate analysis. To simplify the interpretation, we construct an indicator variable, AInstitutional lending high (0/1), which is one if AInstitutional lending is either above the median and zero if it is below its median. We regress the AISD on Europe $(0 / 1)$ as well as an interaction term of Europe (0/1) with $\Delta$ Institutional lending high (0/1) to analyze whether pricing differences between the U.S and Europe are smaller when

\footnotetext{
${ }^{39}$ For example, if institutional term loans in the U.S. account for $50 \%$ of the U.S. term loan volume in a particular year and institutional term loans in Europe accounts for $20 \%$ of the European term loan volume, then IInstitutional lending $=50 \%-20 \%=30 \%$ for that particular year. The variable therefore measures the relative importance of institutional loan supply in the U.S. versus Europe.

${ }^{40}$ Note that for some subsample there are no European observations in some years in the early 1990s.
} 
institutional loan supply is particularly high in the U.S. Moreover, we include our proxy for credit risk discussed in the previous subsection (post-issuance rating changes) as well as the control variables from Panel $\mathrm{C}$ in Table 2. Given that we rely on time-series variation to identify the role of institutional investors on the U.S.-vs.-Europe pricing difference, we use two-way robust standard errors clustered by firm and year. The results are reported in column (1) and (4) of Table 7.

[Table 7 here]

We report results separately for investment-grade and non-investment-grade rated loans. Consistent with the univariate evidence we do not find an effect of institutional investor participation on investment grade term loans. The effect in the non-investment grade subsample, however, is economically large and highly statistically significant. The baseline Europe (0/1) effect is -59bps in the subsample of junk-rated borrowers (column (4)). However, in times of relatively high institutional loan participation in the U.S. the coefficient of Europe (0/1) is $81 \mathrm{bps}$ higher - implying that the baseline Europe (0/1) effect is more than fully offset by the additional institutional loan supply. ${ }^{41}$ To summarize, the relative importance of institutional investors in the U.S. versus Europe is important in understanding differences in term loan spreads between both markets.

\subsubsection{Cross-border activity: Participation from foreign banks}

A third channel that might explain loan spread differences between U.S. and European term loans is the participation of foreign banks in the syndicate. Houston et al. (2014), for example, analyze the cross-sectional determinants of cross-border lending, i.e. which firms and banks are more likely to cross borders. In this paper, we focus on the time series component of cross-border lending. Panel D of Figure 5 depicts the share of foreign loans as a percentage of the total term loan market in the U.S. and Europe. We observe an increasing

\footnotetext{
${ }^{41}$ All results hold when we exclude the financial crisis period, the sovereign debt crisis period, or the pre-1997 period (there is very little institutional investor participation in both markets before 1997).
} 
share of foreign bank loans in the U.S. since 2002, while the percentage is decreasing within Europe.

An increase in foreign bank supply should - all other things being equal - decrease spreads. We introduce a new variable - $\Delta$ Foreign lending - that measures differences in the participation of foreign banks in the U.S. relative to Europe. " $\Delta$ Foreign lending" mimics the definition of $\Delta$ Institutional lending above. In particular, "AForeign lending" is defined as the difference of the ratios of foreign bank term lending volume as percentage of total term loan volume in the U.S. versus Europe in a particular year. This variable is defined on the yearlevel. An increase in the value of this variable from one year to the next implies more foreign bank participation in the U.S. compared with Europe.

Figure 6, Panel B, plots $\Delta$ Foreign lending against the average spread difference between European and U.S. term loans, separately for loans to investment grade and noninvestment grade firms. The univariate evidence suggests a positive correlation between the spread difference and $\Delta$ Foreign lending. That is, European loans are relatively cheaper in years where there is little foreign loan supply in the U.S. relative to Europe. The effect is similar for investment grade and non-investment grade loans.

We next turn to a multivariate analysis. To simplify the interpretation, we construct an indicator variable, $\Delta$ Foreign lending high $(0 / 1)$, which is one if the difference is above the median and zero if it is below its median. We regress the AISD on Europe (0/1) as well as an interaction term of Europe (0/1) with $\Delta$ Foreign lending high (0/1) to analyze whether pricing differences between the U.S and Europe are smaller when foreign bank loan supply is particularly high in the U.S. Moreover, we include our proxy for credit risk discussed in the previous subsection (post-issuance rating changes) as well as the control variables from Panel $\mathrm{C}$ in Table 2. Again, we use two-way robust standard errors clustered by firm and year in all regressions. The results are reported in column (2) and (5) of Table 7. Berger, Makaew, and Turk-Ariss (2015) document that foreign banks lend so safer borrowers compared to domestic 
banks. We thus expect to find the biggest effects in the subsample of investment grade borrowers.

We report results separately for investment-grade and non-investment-grade rated loans. While we do not find an effect of foreign bank lending on non-investment grade term loans, the effect in the investment grade subsample is economically large. The baseline Europe (0/1) effect is -66bps in the subsample of investment-grade borrowers, the interaction term of Europe (0/1) with $\Delta$ Foreign lending high (0/1) is $+86 \mathrm{bps}$. This implies that in times of relatively high foreign bank participation in the U.S. the baseline Europe (0/1) effect is more than fully offset and no significant pricing differences between U.S. and European investment grade loans remains.

Columns (3) and (6) of Table 7 provide regression results that use both the AInstitutional lending high (0/1) variable as well as the $\Delta$ Foreign lending high (0/1) variable. Results from columns (1)-(2) and (4)-(5) are confirmed: Foreign bank lending is a channel that explains loan spread differences between U.S. and European investment-grade term loans. Institutional investor participation, on the other hand, is relevant particularly in the noninvestment-grade market. ${ }^{42}$ Taken together, our results show that a fall in the pricing differential has been accompanied by an increase in institutional investor participation (primarily for non-investment grade borrower) and by an increase in cross-border activity (primarily for investment grade borrowers).

\section{Conclusion}

In this paper, we analyze differences in the pricing of syndicated loans between U.S. and European loans over the 1992-2014 period. Our paper thus adds to the literature initiated by Carey and Nini (2007), who document that interest rate spreads on syndicated loans differed systematically between the European and the U.S. market during the 1992 to 2002 period.

\footnotetext{
${ }^{42}$ All results hold when we exclude the financial crisis period or the sovereign debt crisis period.
} 
First, we explicitly distinguish between term loans and lines of credit and document that, while European borrowers pay lower spreads (AISD) compared to U.S. borrowers, they also pay higher fees for their credit lines. This suggests that the pricing structure for credit lines is different in the U.S. compared to Europe, with the overall total cost of borrowing being very similar across the two markets. We find that U.S. firms draw down their credit lines much more in bad times when either market sources of funding dry up or when firms are doing poorly. A contract with a high AISD and a low AISU - the "U.S.-type" contract provides disincentives for the firm to draw down a credit line. Our results are thus consistent with the idea that U.S. lenders need to shield themselves from draw-downs in bad times - and they do so by increasing the gap between drawn and undrawn costs of credit lines.

Second, we document that pricing differences for term loans between the U.S. and European market are highly volatile over time. We analyze various channels through which differences in U.S. and European term loan spreads can be explained. Specifically, those channels include 1) the composition of term loan borrowers; 2) institutional loan supply, and 3) cross-border activity / loan supply by foreign banks. We find that the composition of borrowers differs between the U.S. and the European term loan markets. In particular, poorercreditworthy U.S. firms are more likely to use term loans compared to European firms. Consistently, we find European term loan issuers have, on average, a significantly better postissue performance compared to U.S. term loan issuers. We find a substantially lower pricing gap between U.S. and European term loans conditioning on firms' post-performance, creditworthiness and profitability differences. Furthermore, we provide evidence that variation in the U.S.-Europe loan cost differential is driven by the participation of institutional investors and the supply of loans by foreign banks. Foreign bank lending predominantly explains loan spread differences between U.S. and European investment-grade term loans. Institutional investor participation, on the other hand, is relevant particularly in the noninvestment-grade market. 


\section{References}

Acharya, V., H. Almeida, F. Ippolito, and A. Perez (2014). Credit lines as monitored liquidity insurance: Theory and evidence, Journal of Financial Economics, 112(3), 287-319.

Acharya, V., B. Imbierowicz, S. Steffen, and D. Teichmann (2016). Does Lack of Financial Stability Impair the Transmission of Monetary Policy? Working Paper.

Acharya, V., and S. Steffen (2016). Capital Markets Union in Europe: Why other Unions Must Lead the Way. Working Paper.

Altman, E. and L. Kao (1992). Rating drift in high-yield bonds, Journal of Fixed Income, 1(4), 15-20.

Berg, T., T. Saunders, and S. Steffen (2016). The Total Costs of Corporate Borrowing in the Loan Market: Don't Ignore the Fees, Journal of Finance, 71(3), 1357-1392.

Berger, A.N., T. Makaew, and R. Turk-Ariss (2015). How Did Foreign Bank Lending Change during the Recent Financial Crisis? Evidence from a Very Comprehensive Dataset, Working paper.

Boot, W.A. and A.V. Thakor (2000). Can Relationship Banking Survive Competition? Journal of Finance 55(2), 679-713.

Carey, M., and G. Nini (2007). Is the corporate loan market globally integrated? A pricing puzzle, Journal of Finance, 62(6), 2969-3007.

Carey, M., M. Post, and S. A. Sharpe (1998). Does Corporate Lending by Banks and Finance Companies Differ? Evidence on Specialization in Private Debt Contracting, Journal of Finance, 53(3), 845-878.

Chava, S. and M. R. Roberts (2008). How does financing impact investment? The role of debt covenants. Journal of Finance 63 (5), 2085-2121.

Cornett, M. M., J. J. McNutt, P. E. Strahan, and H. Tehranian (2011). Liquidity risk management and credit supply in the financial crisis. Journal of Financial Economics, 101, 297-312.

De Fiore, F., and H. Uhlig (2011). Bank Finance versus Bond Finance, Journal of Money, Credit and Banking, 43(7), 1399-1421.

Delianedis, G. and R.L. Geske (2003). Credit risk and risk-neutral default probabilities: information about rating migrations and defaults, EFA 2003 Working Paper. 
Denis, D. J., and V. T. Mihov (2003). The choice among bank debt, non-bank private debt, and public debt: evidence from new corporate borrowings, Journal of Financial Economics, 70(1), 3-28.

Detragiache, E., P. Garella, and L. Guiso (2000). Multiple versus Single Banking Relationships: Theory and Evidence, Journal of Finance 55(3), 1133-1161.

Elsas, R. and J.P. Krahnen (1998). Is relationship lending special? Evidence from credit-file data in Germany, Journal of Banking \& Finance 22(10), 1283-1316.

Esty, B. C., and W. L. Megginson (2003). Creditor rights, enforcement, and debt ownership structure: Evidence from the global syndicated loan market, Journal of Financial and Quantitative Analysis, 38(1), 37-60.

Gande, A. and A. Saunders (2012). Are Banks Still Special When There Is a Secondary Market for Loans? Journal of Finance, Volume 67, Issue 5, 1649-1684.

Gatev, E., T. Schuermann, and P. E. Strahan (2009). Managing Bank Liquidity Risk: How Deposit-Loan Synergies Vary with Market Conditions, Review of Financial Studies, 22(3), 995-1020.

Gatev, E. and P. E. Strahan (2006). Banks' Advantage in Hedging Liquidity Risk: Theory and Evidence from the Commercial Paper Market, Journal of Finance, Volume 66, Issue 2, 867892.

Gatev, E. and P. E. Strahan (2009). Liquidity risk and syndicate structure, Journal of Financial Economics, 93(3), 490-504.

Gaul, L. and P. Uysal (2013). Can equity volatility explain the global loan pricing puzzle? Review of Financial Studies, 26 (12), 3225-3265.

Giannetti, M., and L. Laeven (2012). The flight home effect: Evidence from the syndicated loan market during financial crises, Journal of Financial Economics, 104(1), 23-43.

Giannetti, M., and Y. Yafeh (2012). Do cultural differences between contracting parties matter? Evidence from syndicated bank loans, Management Science, 58(2), 365-383.

Gorton, G and F. A. Schmid (2000). Universal banking and the performance of German firms, Journal of Financial Economics, 58(1-2), 29-80.

Hoshi, T., A. Kashyap, and D. Scharfstein (1993). The Choice Between Public and Private Debt: An Analysis of Post-Deregulation Corporate Financing in Japan, NBER Working Paper No. 4421. 
Houston, J., J. Itzkowitz, and A. Naranjo (2014). Borrowing beyond Borders: Foreign Assets, Lender Choice, and Loan Pricing in the Syndicated Bank Loan Market, Working Paper.

Houston, J., and C. James (1996) Bank Information Monopolies and the Mix of Private and Public Debt Claims, Journal of Finance, 51(5), 1863-1889.

Ivashina, V., and D. Scharfstein (2010). Bank lending during the financial crisis of 2008, Journal of Financial Economics, 97(3), 319-338.

Ivashina, V., and Z. Sun (2011). Institutional Demand Pressure and the Cost of Corporate Loans. Journal of Financial Economics 99, 3, 500-522.

Kashyap, A. K., R. Rajan, and J. C. Stein (2002). Banks as liquidity providers: An explanation for the coexistence of lending and deposit-taking, Journal of Finance, 57(1), 3373.

Kacperczyk, M. and P. Schnabl (2010). When Safe Proved Risky: Commercial Paper during the Financial Crisis of 2007-2009, Journal of Economic Literature 24(1), 29-50.

Löffler, G. (2005). Avoiding the rating bounce: why rating agencies are slow to react to new information, Journal of Economic Behavior \& Organization, 56(3), 365-381.

Massoud, N., D. Nandi, A. Saunders, and K. Song (2011). Do Hedge Funds Trade on Private Information? Evidence from Syndicated Lending and Short Selling? Journal of Financial Economics, 99 (3), 477-499.

Nadauld, T. D., and M. Weisbach (2012). Did Securitization Affect the Cost of Corporate Debt? Journal of Financial Economics, Vol. 105, 332-352.

Norden, L. and M. Weber (2004). Informational efficiency of credit default swap and stock markets: The impact of credit rating announcements, Journal of Banking \& Finance, 28(11), 2813-2843.

Ongena, S. and D.C. Smith (2000). What determines the number of bank relationships? Cross-country evidence, Journal of Financial Intermediation 9(1), 26-56.

Rothschild, M. and J. Stiglitz (1976). Equilibrium in competitive insurance markets: An essay on the economics of imperfect information. Foundations of Insurance Economics, 355-375.

Saunders, A., and S. Steffen (2011). The Costs of Being Private: Evidence from the Loan Market. Review of Financial Studies, 24(12): 4091-4122.

Shivdasani, A., and Y. Wang (2011). Did Structured Credit Fuel the LBO Boom? Journal of Finance, 66, 4, 1291-1321. 


\section{Figure 1. Debt Structure of U.S. and European Firms}

Panel A shows the time series of average firm-level debt structures for public U.S. and European firms. All debt items are depicted as a fraction of total assets. The sample comprises all public non-financial U.S. and European firms covered by Capital IQ. Panel B shows the number of loan issues by loan type and credit quality separately for the U.S. and the European market. The figure is based on all loans in our sample, i.e., loans to rated U.S. and European firms, and covers the 1992-2014 period.

Panel A. Debt Structure - U.S. versus European Firms
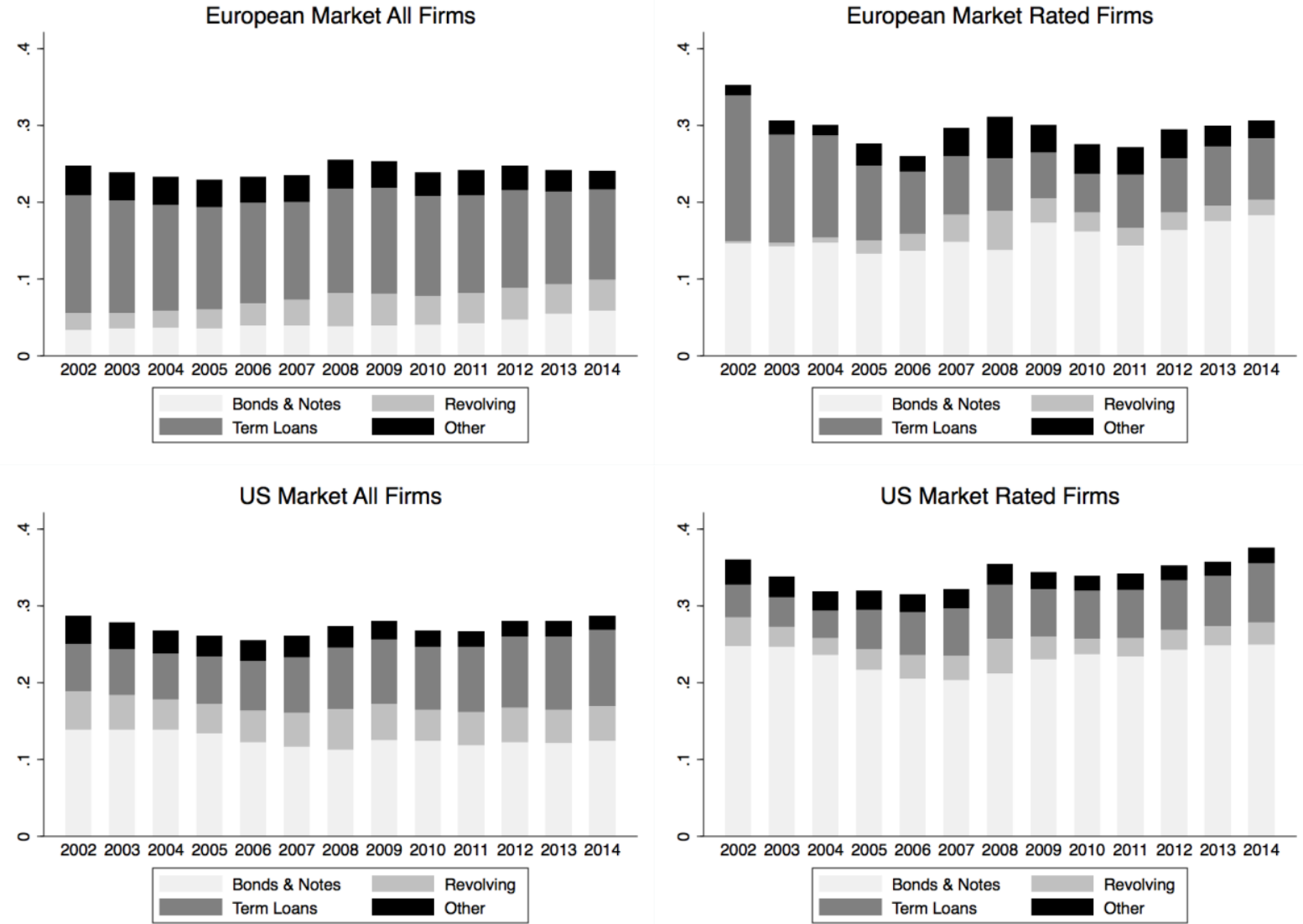

Panel B. Number of Loan Issues by Credit Quality
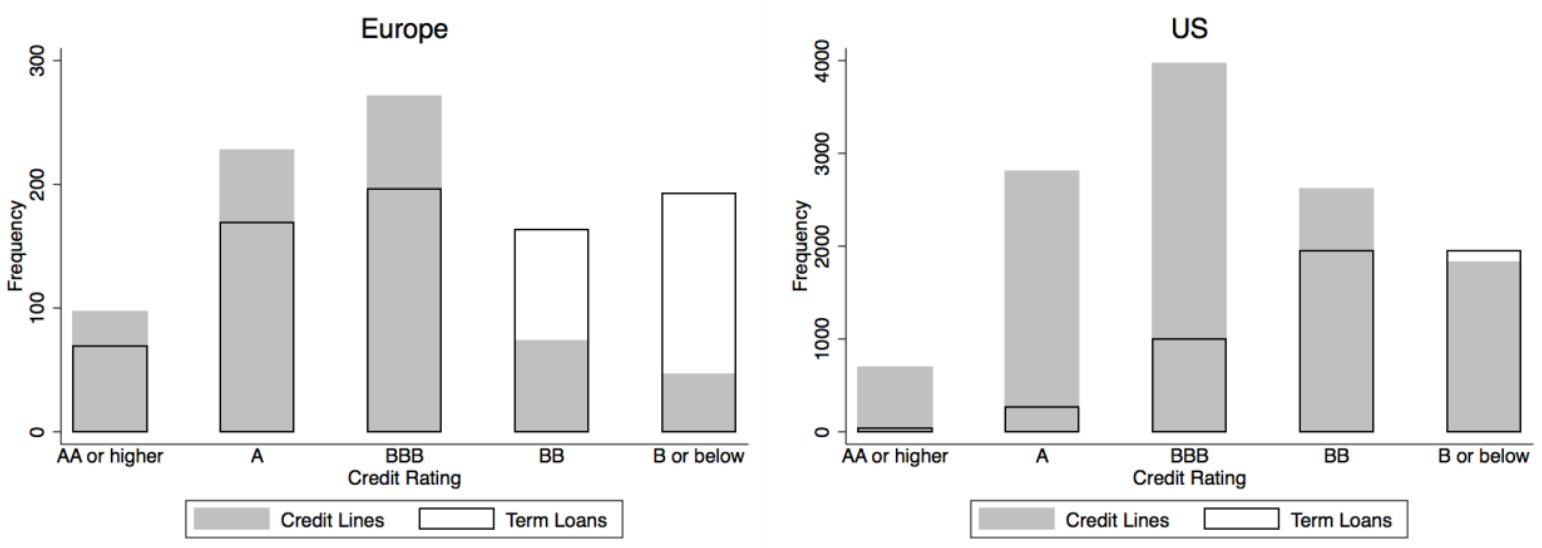


\section{Figure 2}

\section{Pricing Structure in the U.S. and the European Loan Market: AISD versus AISU}

This figure shows the mean AISD and the mean AISU for lines of credit issued by European and U.S. firms, distinguishing between firms that have an investment grade rating and firms that have a junk rating at the time of the loan origination.

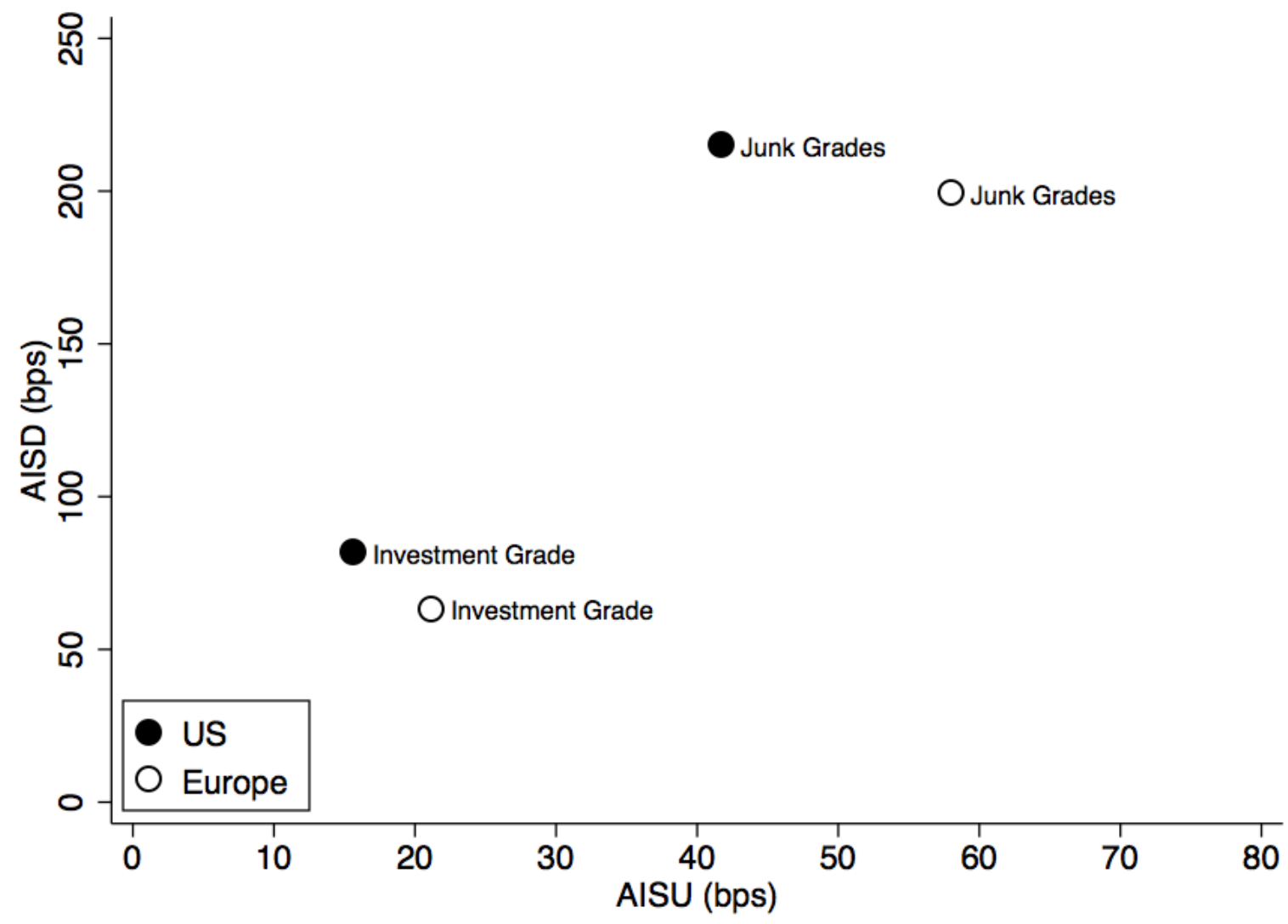




\section{Figure 3}

\section{Credit Line Pricing Puzzle over Time - AISD versus TCB}

This figure shows the European pricing puzzle for credit lines over time. Specifically, we report estimated coefficients from the following regressions:

$$
\begin{gathered}
A I S D=\alpha+\beta_{1}(\text { Europe } * \text { Year } 1992)+\cdots+\beta_{19}(\text { Europe } * \text { Year } 2014)+\delta^{\prime} Y+\varepsilon \\
T C B=\alpha+\beta_{1}(\text { Europe } * \text { Year } 1992)+\cdots+\beta_{19}(\text { Europe } * \text { Year } 2014)+\delta^{\prime} Y+\varepsilon
\end{gathered}
$$

We control for loan purpose, 2-digit SIC code, and credit rating x year fixed effects. $Y$ are control variables to control for heterogeneity in loan characteristics (cf. Panel B of Table 2). The dashed lines represent $95 \%$ confidence intervals, adjusted for firm-level clustering.

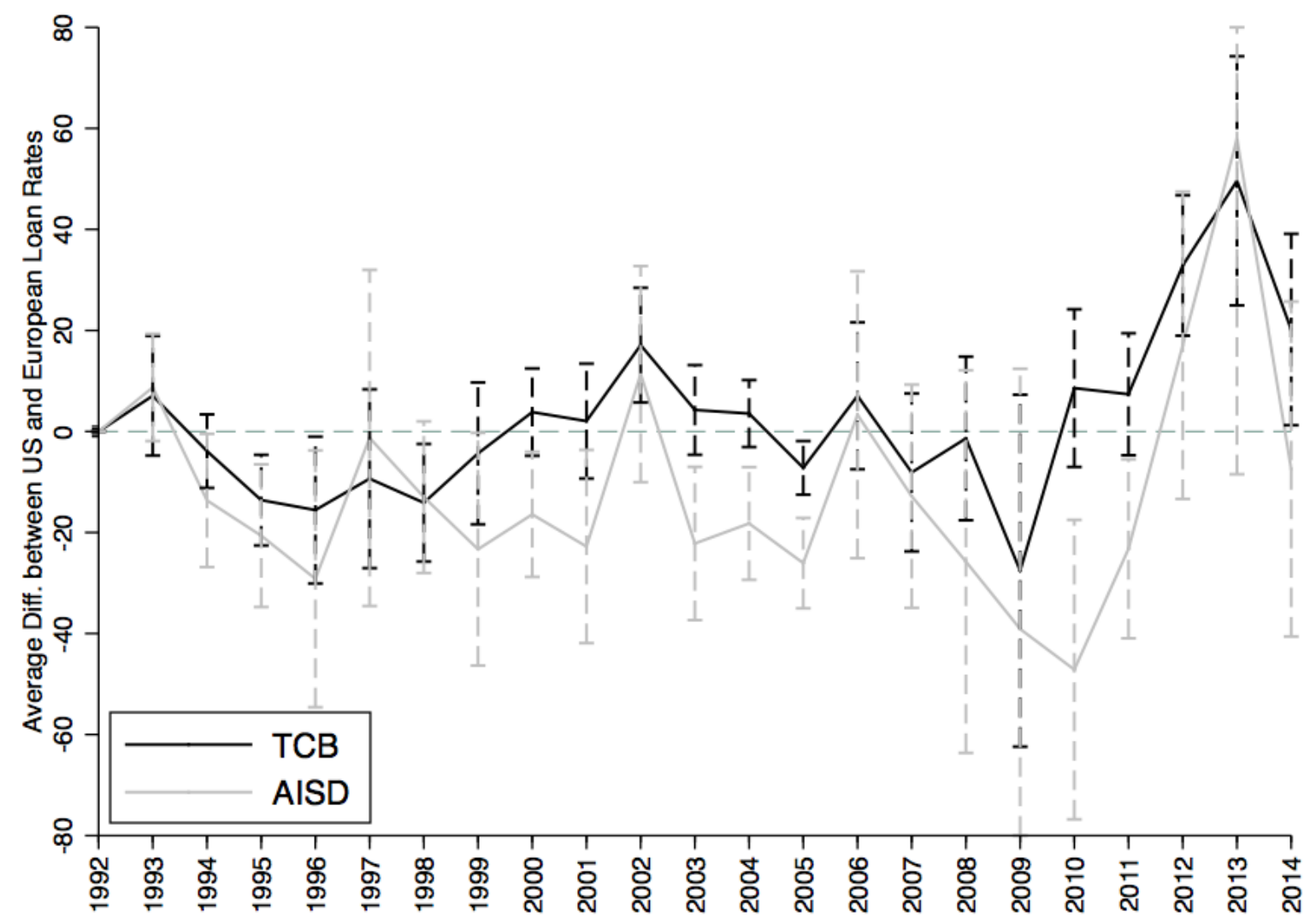




\section{Figure 4}

\section{Post Issue Performance}

This figure shows the change in the credit rating (notch) of the borrower in the year following a loan issue.
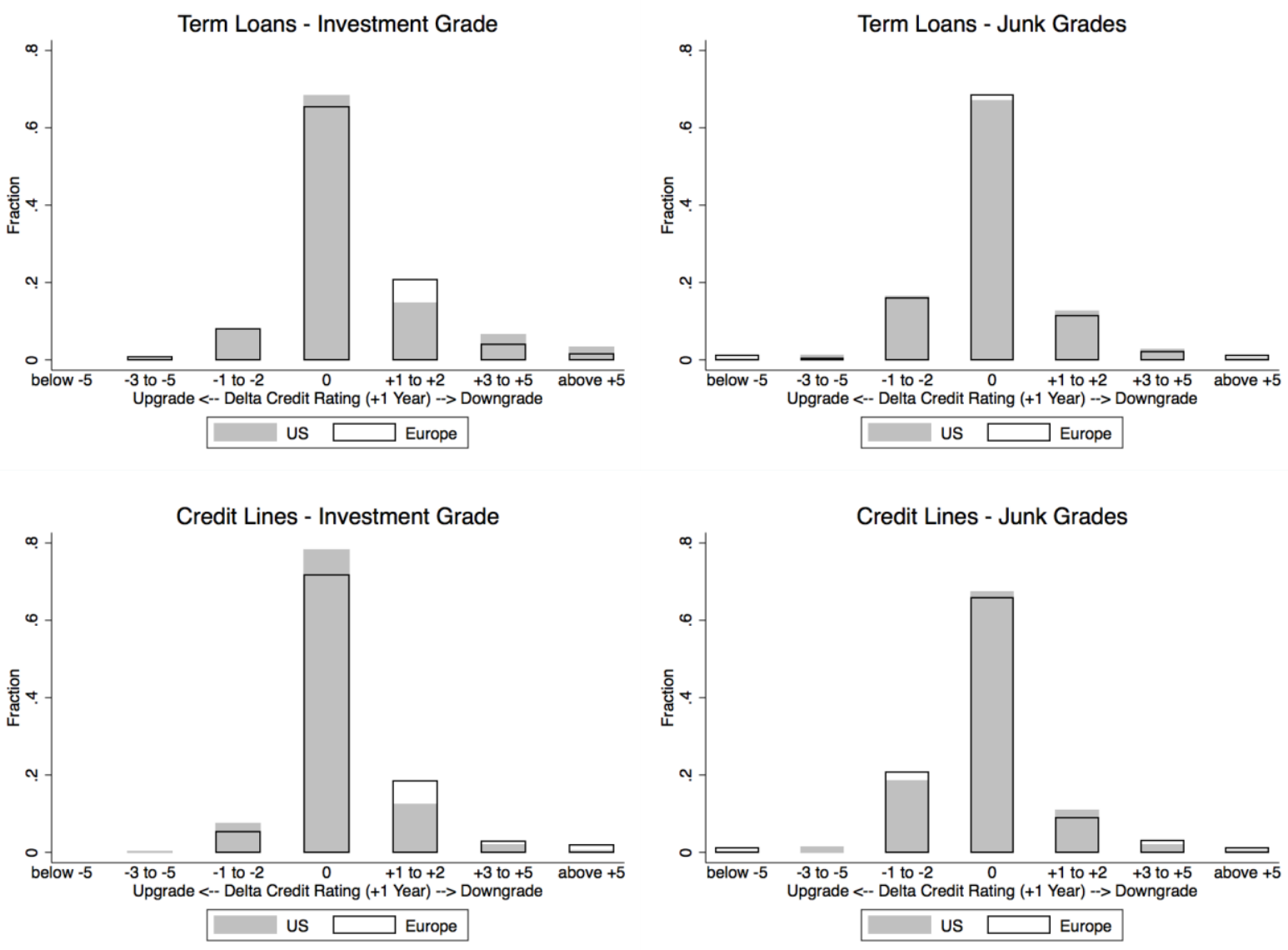


\section{Figure 5}

\section{Term Loan Issuances}

This figure plots the annual loan issuance volume in billion USD in the U.S. versus Europe. Panel A depicts the increase in bank term loan issuance volume (Term A loans), Panel B the increase in institutional term loan issuance volume (Term B loans). Panel C depicts the share of institutional term loan volume. Panel D shows the share of foreign bank loans in total term loan volume. For variable definitions see Appendix A.

\section{Panel A. Bank term loan volume}

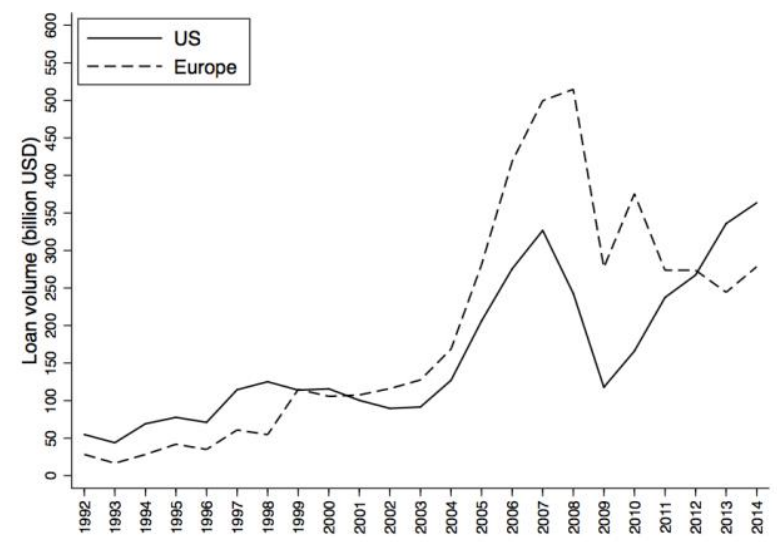

\section{Panel C. Share of institutional term loan volume}

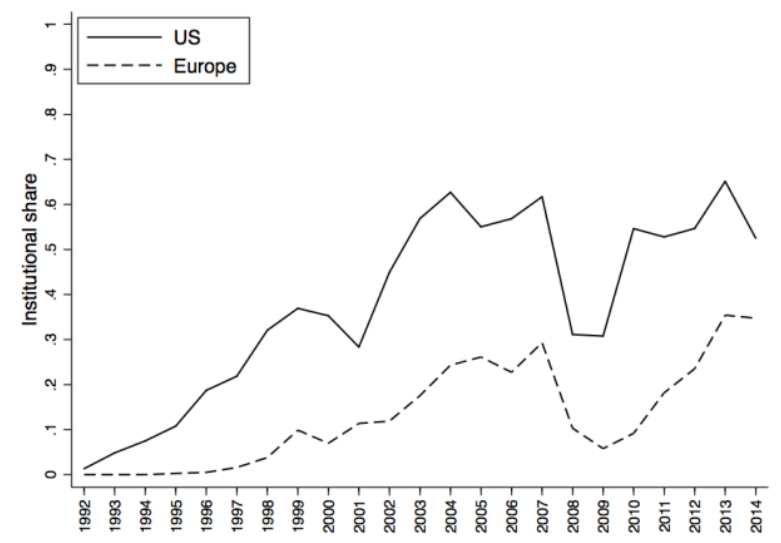

\section{Panel B. Institutional term loan volume}

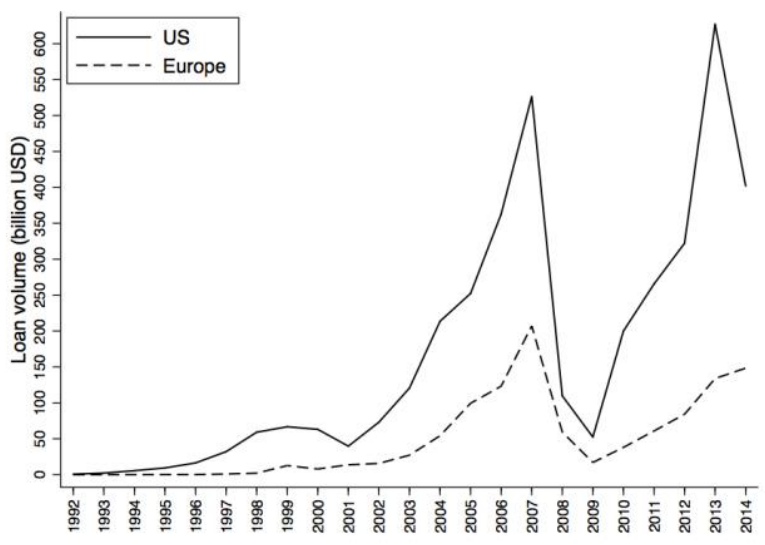

\section{Panel D: Share of foreign bank loan volume}

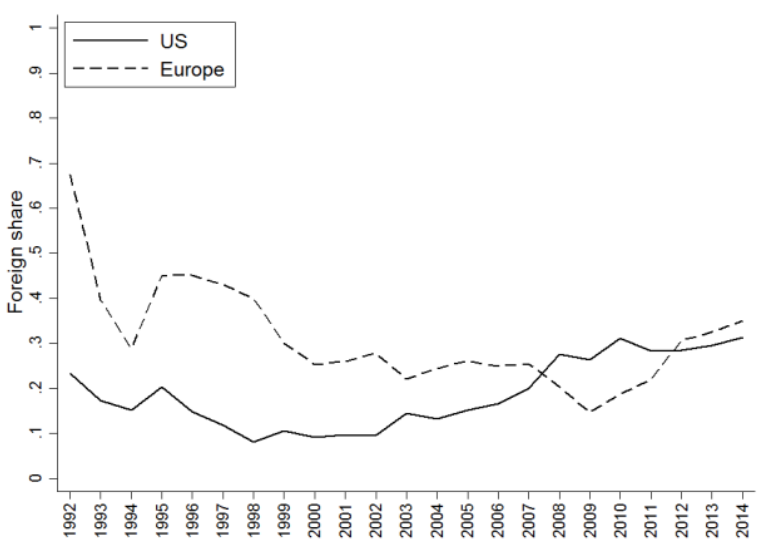




\section{Figure 6}

\section{Institutional and Foreign Lending - Univariate Results}

This figure plots the difference in institutional investor (Panel A) or foreign bank (Panel B) participation in the U.S. versus the European loan market against the average loan pricing difference across the markets (separately for investment grade and junk grade loans). AInstitutional lending ( $\Delta$ Foreign lending) is the difference of the ratios of institutional (foreign) term loan volume as percentage of total term loan volume in the U.S. versus Europe in a particular year (a higher value implies more institutional investor (foreign bank) participation in the U.S. compared with Europe). $\triangle A I S D$ is defined as the difference in the average loan spread in Europe and the U.S. in a given year (a lower value implies that European loans are relatively cheaper compared to U.S. loans).

Panel A: Delta institutional lending versus pricing difference
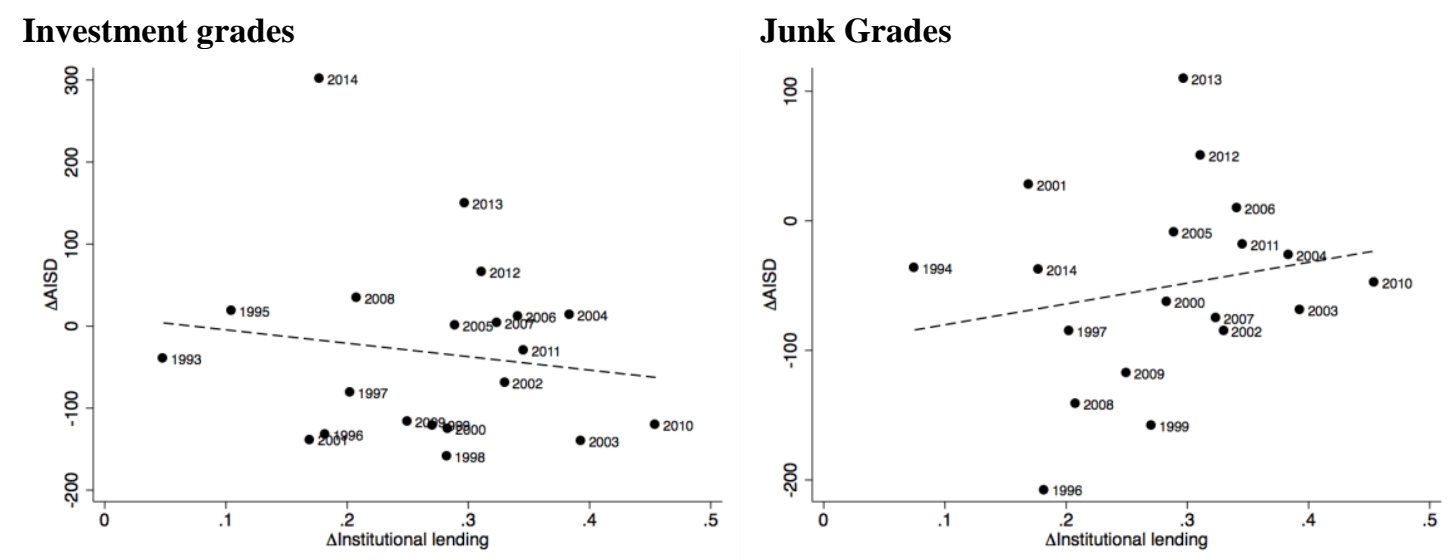

Panel B: Delta foreign lending versus pricing difference

\section{Investment grades}

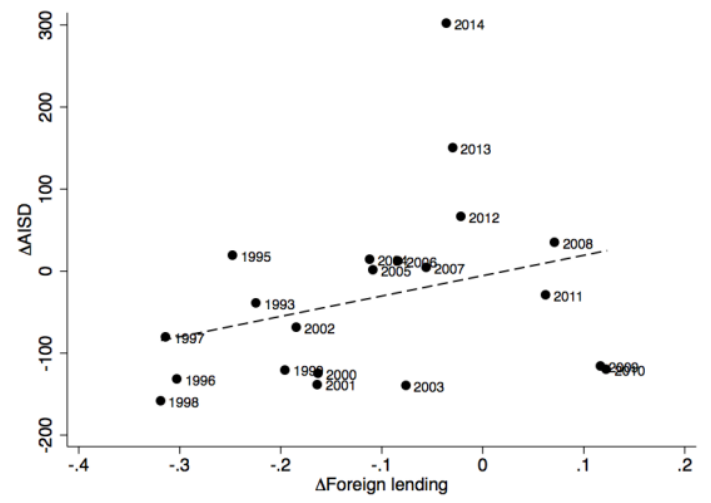

\section{Junk Grades}

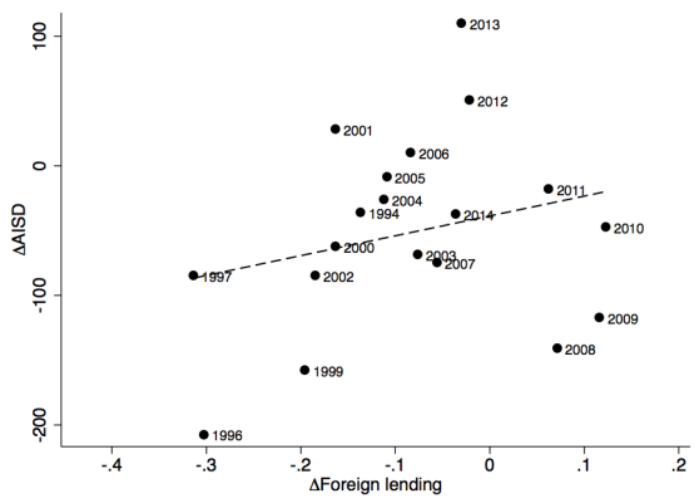


Table 1

\section{Descriptive Statistics}

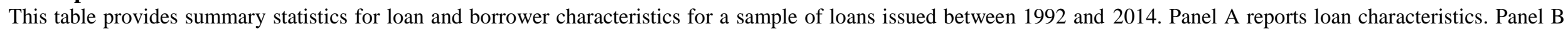
reports borrower characteristics. For variable definitions see Appendix A.

\begin{tabular}{|c|c|c|c|c|c|c|c|c|}
\hline \multirow[b]{2}{*}{ Variable } & \multicolumn{4}{|c|}{ U.S. Market } & \multicolumn{4}{|c|}{ European Market } \\
\hline & Observations & Mean & Median & Std & Observations & Mean & Median & Std \\
\hline \multicolumn{9}{|l|}{ Panel A: Loan Characteristics } \\
\hline AISD & 17,717 & 176.08 & 150.00 & 141.10 & 1,735 & 170.79 & 115.00 & 162.08 \\
\hline Revolver (0/1) & 17,717 & 0.67 & 1.00 & 0.47 & 1,735 & 0.41 & 0.00 & 0.49 \\
\hline Facility Amount (million USD) & 17,717 & 588.34 & 300.00 & 726.47 & 1,735 & 985.43 & 548.00 & $1,060.07$ \\
\hline Maturity (months) & 17,717 & 47.52 & 60.00 & 24.27 & 1,735 & 57.06 & 60.00 & 29.93 \\
\hline Maturity $1-3 y r(0 / 1)$ & 17,717 & 0.24 & 0.00 & 0.43 & 1,735 & 0.20 & 0.00 & 0.40 \\
\hline Maturity 3-6yr (0/1) & 17,717 & 0.62 & 1.00 & 0.49 & 1,735 & 0.53 & 1.00 & 0.50 \\
\hline Maturity $>6 \mathrm{yr}(0 / 1)$ & 17,717 & 0.11 & 0.00 & 0.31 & 1,735 & 0.25 & 0.00 & 0.44 \\
\hline Purpose: Takeover (0/1) & 17,717 & 0.10 & 0.00 & 0.30 & 1,735 & 0.13 & 0.00 & 0.34 \\
\hline Purpose: Other $(0 / 1)$ & 17,717 & 0.38 & 0.00 & 0.49 & 1,735 & 0.46 & 0.00 & 0.50 \\
\hline Purpose: General Corporate (0/1) & 17,717 & 0.40 & 0.00 & 0.49 & 1,735 & 0.35 & 0.00 & 0.48 \\
\hline Purpose: Project Finance $(0 / 1)$ & 17,717 & 0.00 & 0.00 & 0.07 & 1,735 & 0.03 & 0.00 & 0.17 \\
\hline Purpose: CP Backup (0/1) & 17,717 & 0.11 & 0.00 & 0.31 & 1,735 & 0.02 & 0.00 & 0.16 \\
\hline Secured $(0 / 1)$ & 17,717 & 0.39 & 0.00 & 0.49 & 1,735 & 0.29 & 0.00 & 0.45 \\
\hline $\ln (\#$ Lenders) & 17,717 & 2.05 & 2.20 & 0.93 & 1,735 & 2.10 & 2.30 & 1.08 \\
\hline Syndicate HHI & 17,717 & $2,152.01$ & $1,250.00$ & $2,454.63$ & 1,735 & $2,068.14$ & $1,000.00$ & $2,574.94$ \\
\hline \multicolumn{9}{|l|}{ Panel B: Borrower Characteristics } \\
\hline Rating: AAA $(0 / 1)$ & 17,717 & 0.01 & 0.00 & 0.09 & 1,735 & 0.01 & 0.00 & 0.12 \\
\hline Rating: AA (0/1) & 17,717 & 0.03 & 0.00 & 0.18 & 1,735 & 0.10 & 0.00 & 0.30 \\
\hline Rating: A (0/1) & 17,717 & 0.18 & 0.00 & 0.39 & 1,735 & 0.26 & 0.00 & 0.44 \\
\hline Rating: BBB (0/1) & 17,717 & 0.29 & 0.00 & 0.46 & 1,735 & 0.31 & 0.00 & 0.46 \\
\hline Rating: BB $(0 / 1)$ & 17,717 & 0.26 & 0.00 & 0.44 & 1,735 & 0.16 & 0.00 & 0.36 \\
\hline Rating: B (0/1) & 17,717 & 0.22 & 0.00 & 0.41 & 1,735 & 0.16 & 0.00 & 0.37 \\
\hline
\end{tabular}


Table 2

\section{Base Regression (Carey and Nini (2007) Specification)}

This table provides results of a linear regression of the loan interest rate (AISD) on a European market dummy (Europe (0/1)) and control variables. Ln(Facility Amount) is the natural log of the loan amount. Maturity 1-3yr (0/1) is an indicator variable equal to 1 if the maturity of the loan is between 1 and 3 years. Maturity 3-6yr (0/1) is an indicator variable if the maturity of the loan is between 3 and 6 years. Maturity >6yr $(0 / 1)$ is an indicator variable equal to 1 if the loan maturity is above 6 years. Loans with a maturity below 1 year are the omitted group. Secured $(0 / 1)$ is an indicator variable equal to 1 if the loan is secured. Term Loan $(0 / 1)$ is an indicator variable equal to 1 if the loan is a term loan. Bridge Loan (0/1) is an indicator variable equal to 1 if the loan is a bridge loan. Other Loan (0/1) is an indicator variable equal to 1 if the loan is neither a credit line or a term loan nor a bridge loan. $\ln (\#$ Lenders) is the natural logarithm of the number of banks in the loan syndicate. Syndicate HHI is a concentration measure defined as the sum of the squared loan shares. For variable definitions see Appendix A. Column (1) reports the results for the full sample, column (2) for investment grade loans (I-Grade), column (3) for non-investment grade loans (Junk). Columns (4) and (5) split the sample into credit lines and term loans, respectively. Fixed effects for loan purpose, year, two-digit SIC code, and borrower credit rating are included but the coefficients are not shown. Panel A uses the Carey and Nini (207) specification and a sample over the 1992 to 2002 period. Panel B introduces additional control variables. Panel $\mathrm{C}$ extends the sample to the end of 2014. We report $\mathrm{t}$-values based on standard errors clustered at the borrowing firm in parentheses. $* * *, * * *$ denote significance at the 1,5 and 10 $\%$ level, respectively.

Panel A. Carey and Nini (2007) specifications

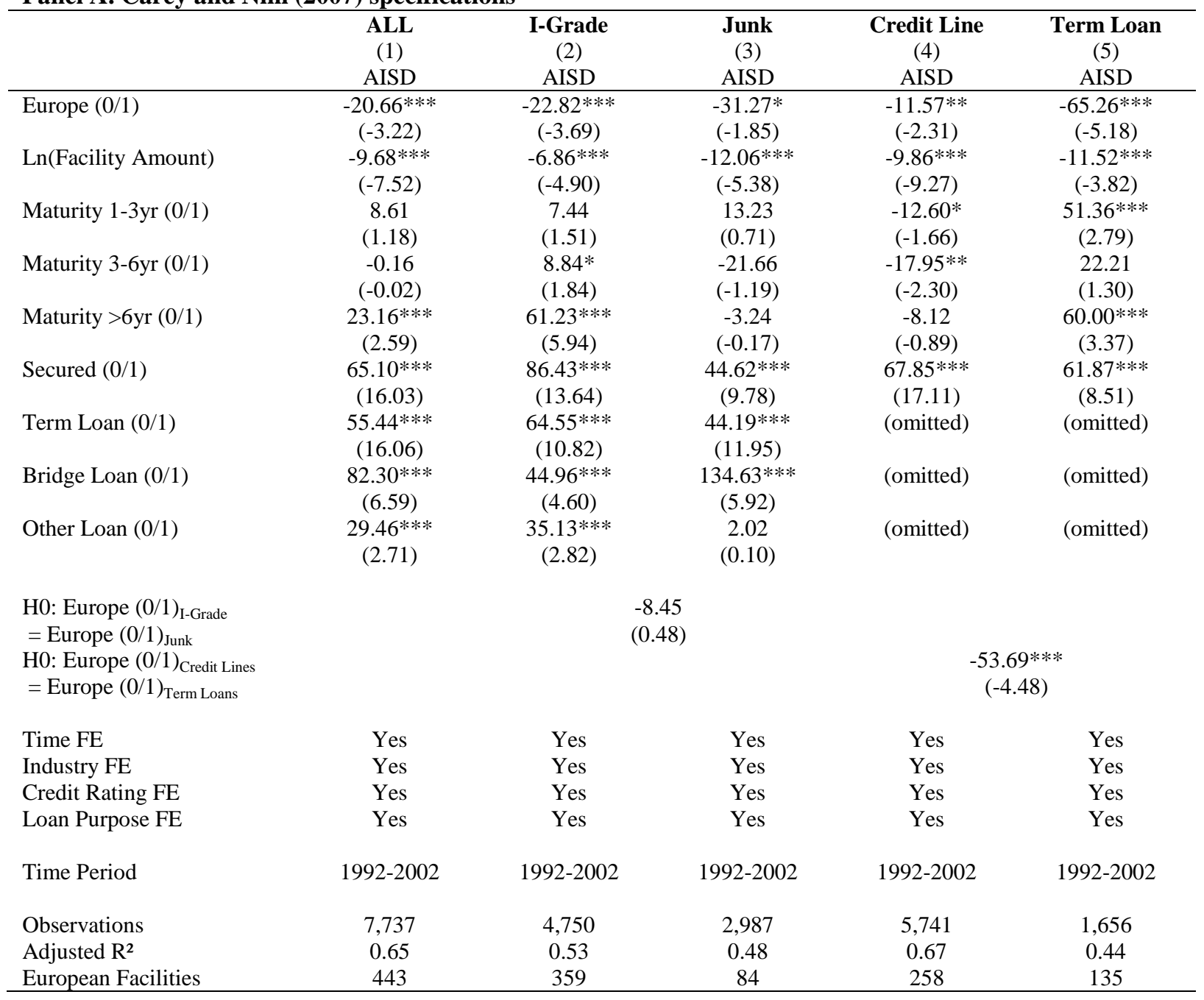


Panel B. Carey and Nini (2007) specifications - additional controls

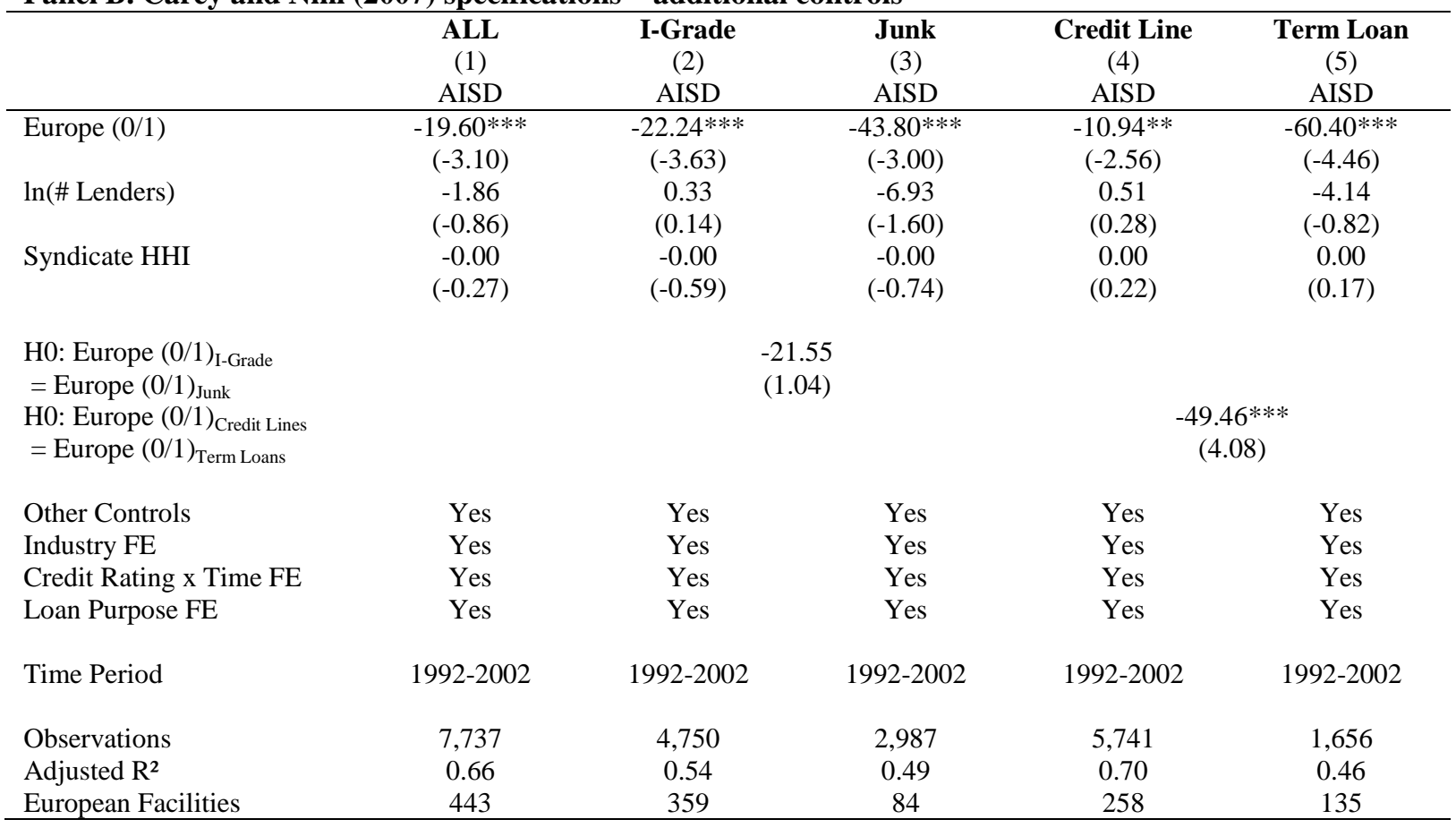

Panel C. Period extension (1992 - 2014)

\begin{tabular}{|c|c|c|c|c|c|}
\hline & $\begin{array}{c}\text { ALL } \\
(1) \\
\text { AISD } \\
\end{array}$ & $\begin{array}{c}\text { I-Grade } \\
(2) \\
\text { AISD } \\
\end{array}$ & $\begin{array}{c}\text { Junk } \\
(3) \\
\text { AISD } \\
\end{array}$ & $\begin{array}{c}\text { Credit Line } \\
(4) \\
\text { AISD } \\
\end{array}$ & $\begin{array}{c}\text { Term Loan } \\
(5) \\
\text { AISD } \\
\end{array}$ \\
\hline Europe $1992-2002(0 / 1)$ & $\begin{array}{c}-22.50 * * * \\
(-3.34)\end{array}$ & $\begin{array}{c}-27.19^{* * *} \\
(-4.22)\end{array}$ & $\begin{array}{c}-48.54^{* * * *} \\
(-2.88)\end{array}$ & $\begin{array}{c}-10.68^{* *} \\
(-2.30)\end{array}$ & $\begin{array}{c}-49.07 * * * \\
(-3.36)\end{array}$ \\
\hline Europe 2003 - $2007(0 / 1)$ & $\begin{array}{c}-3.16 \\
(-0.43)\end{array}$ & $\begin{array}{c}-21.22 * * * \\
(-3.12)\end{array}$ & $\begin{array}{c}1.97 \\
(0.17)\end{array}$ & $\begin{array}{c}-18.44 * * * \\
(-4.96)\end{array}$ & $\begin{array}{c}4.64 \\
(0.41)\end{array}$ \\
\hline Europe 2008 - $2010(0 / 1)$ & $\begin{array}{c}-47.22 * * * \\
(-3.25)\end{array}$ & $\begin{array}{c}-40.26 * * * \\
(-2.83)\end{array}$ & $\begin{array}{c}-71.42 * * * \\
(-3.46)\end{array}$ & $\begin{array}{c}-39.48 * * * \\
(-3.54)\end{array}$ & $\begin{array}{c}-53.99 * * * \\
(-2.63)\end{array}$ \\
\hline Europe 2011 - $2014(0 / 1)$ & $\begin{array}{c}39.19 * * * \\
(3.00)\end{array}$ & $\begin{array}{c}36.72 * * \\
(2.24)\end{array}$ & $\begin{array}{c}28.47 * * \\
(1.98)\end{array}$ & $\begin{array}{c}4.72 \\
(0.46)\end{array}$ & $\begin{array}{c}64.98 * * * \\
(3.61)\end{array}$ \\
\hline Other Controls & Yes & Yes & Yes & Yes & Yes \\
\hline Industry FE & Yes & Yes & Yes & Yes & Yes \\
\hline Credit Rating $x$ Time FE & Yes & Yes & Yes & Yes & Yes \\
\hline Loan Purpose FE & Yes & Yes & Yes & Yes & Yes \\
\hline Time Period & $1992-2014$ & $1992-2014$ & 1992-2014 & $1992-2014$ & $1992-2014$ \\
\hline Observations & 19,402 & 10,352 & 9,050 & 12,600 & 5,923 \\
\hline Adjusted $\mathrm{R}^{2}$ & 0.63 & 0.57 & 0.48 & 0.72 & 0.48 \\
\hline European Facilities & 1,685 & 1,179 & 506 & 708 & 750 \\
\hline
\end{tabular}


Table 3

\section{Credit Lines: AISD versus AISU - Multivariate Results}

This table provides results of a linear regression of loan pricing terms on Europe (0/1) and control variables as reported in Panel B of Table 2. The coefficients are not shown for brevity, a variable definition is provided in Appendix A. Fixed effects for loan purpose, two-digit SIC code, and borrower credit rating x year as well as other loan characteristics are included but not shown. The dependent variables are as follows: AISD in column (1), AISU in column (2), an undrawn weighted spread (UWS) with different drawdown assumptions $(30 \%, 25 \%$, and $20 \%$ ) in columns (3) to (5), and the $T C B$ in column (6). We report t-values based on standard errors clustered at the borrowing firm in parentheses. ***, **, * denote significance at the 1, 5 and $10 \%$ level, respectively.

\begin{tabular}{|c|c|c|c|c|c|c|}
\hline Sample: & $\begin{array}{c}\text { Credit } \\
\text { Lines } \\
(1) \\
\text { AISD } \\
\end{array}$ & $\begin{array}{c}\text { Credit } \\
\text { Lines } \\
(2) \\
\text { AISU }\end{array}$ & $\begin{array}{c}\begin{array}{c}\text { Credit } \\
\text { Lines } \\
(3)\end{array} \\
\text { UWS }(30 \%)\end{array}$ & $\begin{array}{c}\begin{array}{c}\text { Credit } \\
\text { Lines } \\
(4)\end{array} \\
\text { UWS }(25 \%)\end{array}$ & 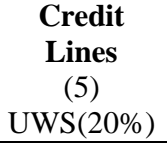 & $\begin{array}{c}\text { Credit } \\
\text { Lines } \\
(6) \\
\text { TCB } \\
\end{array}$ \\
\hline Europe $1992-2002(0 / 1)$ & $\begin{array}{c}-10.68 * * \\
(-2.30)\end{array}$ & $\begin{array}{c}6.51 * * * \\
(4.92)\end{array}$ & $\begin{array}{c}1.35 \\
(0.63)\end{array}$ & $\begin{array}{c}2.21 \\
(1.11)\end{array}$ & $\begin{array}{c}3.07 * \\
(1.66)\end{array}$ & $\begin{array}{c}2.53 \\
(0.88)\end{array}$ \\
\hline Europe $2003-2007(0 / 1)$ & $\begin{array}{c}-18.44 * * * \\
(-4.96)\end{array}$ & $\begin{array}{c}3.11 * * * \\
(2.63)\end{array}$ & $\begin{array}{l}-3.35^{*} \\
(-1.91)\end{array}$ & $\begin{array}{c}-2.27 \\
(-1.39)\end{array}$ & $\begin{array}{l}-1.20 \\
(-0.78)\end{array}$ & $\begin{array}{c}-0.21 \\
(-0.10)\end{array}$ \\
\hline Europe $2008-2010(0 / 1)$ & $\begin{array}{c}-39.48 * * * \\
(-3.54)\end{array}$ & $\begin{array}{c}11.07 * * * \\
(3.03)\end{array}$ & $\begin{array}{c}-4.09 \\
(-0.78)\end{array}$ & $\begin{array}{c}-1.57 \\
(-0.32)\end{array}$ & $\begin{array}{c}0.96 \\
(0.21)\end{array}$ & $\begin{array}{c}-2.48 \\
(-0.39)\end{array}$ \\
\hline Europe 2011 - 2014 (0/1) & $\begin{array}{c}4.72 \\
(0.46)\end{array}$ & $\begin{array}{c}22.94 * * * \\
(5.77)\end{array}$ & $\begin{array}{c}17.48 * * * \\
(3.16)\end{array}$ & $\begin{array}{c}18.39 * * * \\
(3.51)\end{array}$ & $\begin{array}{c}19.30 * * * \\
(3.90)\end{array}$ & $\begin{array}{c}24.19 * * * \\
(4.79)\end{array}$ \\
\hline Other Controls & Yes & Yes & Yes & Yes & Yes & Yes \\
\hline Industry FE & Yes & Yes & Yes & Yes & Yes & Yes \\
\hline Credit Rating x Time FE & Yes & Yes & Yes & Yes & Yes & Yes \\
\hline Loan Purpose FE & Yes & Yes & Yes & Yes & Yes & Yes \\
\hline Observations & 12,600 & 12,600 & 12,600 & 12,600 & 12,600 & 11,527 \\
\hline Adjusted $\mathrm{R}^{2}$ & 0.72 & 0.65 & 0.73 & 0.72 & 0.72 & 0.66 \\
\hline European Facilities & 708 & 708 & 708 & 708 & 708 & 655 \\
\hline
\end{tabular}


Table 4

\section{Usage of Credit Lines and Economic Performance - Univariate Results}

This table presents the usage of credit lines by economic performance. Usage is measured as the percentage usage of the credit line at fiscal year-end using annual report data from CapitalIQ. Economic performance is measured as the equity return over the prior 12 months. Panel A provides results by quintile of equity return. These quintiles are determined separately for the U.S. and for Europe. Panel B also provides results by quintile of equity return. However, in Panel B quintiles are created using the same break points for the U.S. and Europe. The sample is based on credit lines in the U.S. syndicated loan market from 2000 to 2014 for which information related to the usage is available in CapitalIQ. The sample includes both rated and unrated firms. For variable definitions see Appendix A. ***, **, and $*$ denote significance at the $1 \%, 5 \%$, and $10 \%$ level, respectively.

\begin{tabular}{|c|c|c|c|}
\hline \multicolumn{4}{|c|}{$\begin{array}{l}\text { Usage rates by quintile of Equity Return (prior } 12 \text { months) and Region } \\
\text { Quintiles by equity return and region }\end{array}$} \\
\hline Quintile & $\begin{array}{c}\text { US } \\
(\mathrm{N}=9,896)\end{array}$ & $\begin{array}{c}\text { Europe } \\
(\mathrm{N}=1,785)\end{array}$ & US - Europe \\
\hline 1 (Lowest equity return) & $33.38 \%$ & $26.70 \%$ & $6.68 \% * * *$ \\
\hline 2 & $24.10 \%$ & $20.80 \%$ & $3.30 \% * *$ \\
\hline 3 & $20.72 \%$ & $19.50 \%$ & $1.22 \%$ \\
\hline 4 & $19.73 \%$ & $19.22 \%$ & $0.51 \%$ \\
\hline 5 (Highest equity return) & $22.26 \%$ & $21.01 \%$ & $1.26 \%$ \\
\hline Q1-Q5 & $11.12 \% * * *$ & $5.69 \% * *$ & \\
\hline t-statistic & (11.70) & $(2.57)$ & \\
\hline
\end{tabular}

\begin{tabular}{lccc}
\hline $\begin{array}{l}\text { Usage rates by quintile of Equity Return (prior 12 months) and Region } \\
\text { Quintiles by equity return only (i.e., using the same break points for the U.S. and Europe) }\end{array}$ \\
\hline Quintile & US & Europe & US - Europe \\
& $(\mathrm{N}=9,896)$ & $(\mathrm{N}=1,785)$ & \\
\hline 1 (Lowest equity return) & $33.37 \%$ & $26.56 \%$ & $6.80 \% * * *$ \\
2 & $23.90 \%$ & $21.38 \%$ & $2.52 \%$ \\
3 & $20.77 \%$ & $19.54 \%$ & $1.23 \%$ \\
4 & $19.71 \%$ & $19.01 \%$ & $0.69 \%$ \\
5 (Highest equity return) & $22.28 \%$ & $21.30 \%$ & $0.98 \%$ \\
\hline Q1 - Q5 & $11.09 \% * * *$ & $5.27 \% * *$ & \\
t-statistic & $(11.74)$ & $(2.32)$ & \\
\hline
\end{tabular}


Table 5

\section{Usage of Credit Lines and Economic Performance - Multivariate Results}

This table provides results of a linear regression of the usage of credit lines on economic performance and control variables. Usage is measured as the percentage usage of the credit line at fiscal year-end using annual report data from CapitalIQ. Economic performance is measured as the equity return over the prior 12 months. Columns (1) and (2) provide results for rated and unrated firms, columns (3) and (4) provide results for rated firms only and columns (5) and (6) provide results for unrated firms only. Column (1), (3), and (5) use a firms equity return as the main independent variable, columns (2), (4), and (6) split this return into the respective index return (by country) and the excess return - defined as equity return minus the index return. Fixed effects for loan purpose, two-digit SIC code, and borrower credit rating as well as other loan characteristics are included but not shown. The sample is based on credit lines in the U.S. syndicated loan market from 2000 to 2014 for which information related to the usage is available in CapitalIQ. For variable definitions see Appendix A. We report tvalues based on standard errors clustered at the borrowing firm and year level (Petersen, 2009) in parentheses. $* * *, * *$, and $*$ denote significance at the $1 \%, 5 \%$, and $10 \%$ level, respectively.

\begin{tabular}{|c|c|c|c|c|c|c|}
\hline & \multicolumn{2}{|c|}{ Rated and unrated } & \multicolumn{2}{|c|}{ Rated firms only } & \multicolumn{2}{|c|}{ Unrated firms only } \\
\hline & (1) & (2) & (3) & (4) & (5) & (6) \\
\hline Variable & Usage & Usage & Usage & Usage & Usage & Usage \\
\hline Europe $(0 / 1)$ & $\begin{array}{l}0.004 \\
(0.29)\end{array}$ & $\begin{array}{l}-0.001 \\
(-0.05)\end{array}$ & $\begin{array}{l}0.008 \\
(0.40)\end{array}$ & $\begin{array}{l}-0.003 \\
(-0.14)\end{array}$ & $\begin{array}{l}-0.002 \\
(-0.09)\end{array}$ & $\begin{array}{c}0.001 \\
(-0.04)\end{array}$ \\
\hline Europe $(0 / 1) \times$ Equity return & $\begin{array}{c}-0.046^{*} \\
(-1.80)\end{array}$ & & $\begin{array}{l}-0.043 \\
(-1.13)\end{array}$ & & $\begin{array}{c}-0.047^{*} \\
(-1.79)\end{array}$ & \\
\hline US $(0 / 1)$ x Equity return & $\begin{array}{c}-0.093 * * * \\
(-8.14)\end{array}$ & & $\begin{array}{c}-0.083 * * * \\
(-4.94)\end{array}$ & & $\begin{array}{c}-0.098 * * * \\
(-9.76)\end{array}$ & \\
\hline Europe $(0 / 1) \mathrm{x}$ Index return & & $\begin{array}{c}-0.164 * * * \\
(-5.87)\end{array}$ & & $\begin{array}{c}-0.128 * * * \\
(-3.70)\end{array}$ & & $\begin{array}{c}-0.186 * * * \\
(-7.67)\end{array}$ \\
\hline US $(0 / 1) \times$ Index return & & $\begin{array}{c}-0.206^{* * * *} \\
(-6.97)\end{array}$ & & $\begin{array}{c}-0.245 * * * \\
(-6.68)\end{array}$ & & $\begin{array}{c}-0.169 * * * \\
(-7.05)\end{array}$ \\
\hline Europe $(0 / 1)$ x Excess return & & $\begin{array}{l}0.004 \\
(0.21)\end{array}$ & & $\begin{array}{l}0.007 \\
(0.19)\end{array}$ & & $\begin{array}{l}0.007 \\
(0.25)\end{array}$ \\
\hline US $(0 / 1) \times$ Excess return & & $\begin{array}{l}-0.065^{* * *} \\
(-7.98)\end{array}$ & & $\begin{array}{c}-0.039 * * * \\
(-2.99)\end{array}$ & & $\begin{array}{c}-0.081 * * * \\
(-7.54)\end{array}$ \\
\hline Other Controls (w/o year FE) & Yes & Yes & Yes & Yes & Yes & Yes \\
\hline Industry FE & Yes & Yes & Yes & Yes & Yes & Yes \\
\hline Credit Rating FE & Yes & Yes & Yes & Yes & Yes & Yes \\
\hline Loan Purpose FE & Yes & Yes & Yes & Yes & Yes & Yes \\
\hline Time Period & $2000-2014$ & $2000-2014$ & 2000-2014 & $2000-2014$ & 2000-2014 & $2000-2014$ \\
\hline Observations & 10,716 & 10,708 & 4,731 & 4,730 & 5,985 & 5,978 \\
\hline Adjusted R² & 0.13 & 0.13 & 0.11 & 0.13 & 0.13 & 0.14 \\
\hline $\begin{array}{l}\text { Diagnostic Section } \\
\text { Europe } x \text { Equity return }=U S_{x}\end{array}$ & quity return & & & & & \\
\hline $\begin{array}{l}\text { Difference } \\
\text { F-stat }\end{array}$ & $\begin{array}{l}-0.047 * * * \\
\quad(8.06)\end{array}$ & & $\begin{array}{l}-0.040 \\
(2.60)\end{array}$ & & $\begin{array}{l}-0.051 * * \\
(5.07)\end{array}$ & \\
\hline Europe $x$ Index return $=U S x$ & lex return & & & & & \\
\hline $\begin{array}{l}\text { Difference } \\
\text { F-stat }\end{array}$ & & $\begin{array}{l}-0.042 * * * \\
\quad(9.57)\end{array}$ & & $\begin{array}{c}-0.117 * * * \\
(16.24)\end{array}$ & & $\begin{array}{l}0.017 \\
(0.75)\end{array}$ \\
\hline $\begin{array}{l}\text { Europe } x \text { Excess return }=U S \\
\text { Difference } \\
\text { F-stat }\end{array}$ & xcess return & $\begin{array}{c}-0.069 * * * \\
(11.36) \\
\end{array}$ & & $\begin{array}{l}-0.046 \\
(1.34) \\
\end{array}$ & & $\begin{array}{c}-0.088 * * * \\
(10.31) \\
\end{array}$ \\
\hline
\end{tabular}


Table 6

\section{Ex-Post Performance}

Panel A of this table provides results of linear regressions of post loan issue changes in borrower credit rating $(\Delta$ Rating $(+1 Y))$ and profitability $(\triangle$ Prof. $(+1 Y))$ on a European market dummy and control variables as reported in Panel B of Table 2. $\Delta$ Rating is defined as the difference in rating notches between $\mathrm{t}+1$ (one year after the loan issue) and $t=0$ (rating at loan origination). Positive (negative) values indicate downgrades (upgrades). $\Delta$ Prof. is defined as the difference in profitability at $\mathrm{t}+1$ and $\mathrm{t}=0$. Positive (negative) values indicate profitability increases (decreases). Panel B of this table provides results of a linear regression of the term loan loan interest rate (AISD) on a European market dummy (Europe $(0 / 1)$ ), post-issuance performance measured via changes in the borrower credit rating, and control variables. Control variables are the same as in Panel C of Table 2. In both panels, columns (1) and (2) report results for investment-grade borrowers and columns (3) and (4) report results for junk rated borrowers. For variable definitions see Appendix A. Fixed effects for loan purpose, two-digit SIC code, and borrower credit rating $\mathrm{x}$ year as well as other loan characteristics are included but not shown. We report $\mathrm{t}$ values based on standard errors clustered at the borrowing firm in parentheses. $* * *, * *$, denote significance at the 1,5 and $10 \%$ level, respectively.

\section{Panel A: Ex-post performance}

\section{Term Loans}

I-Grade

(2)

(1)

$\Delta$ Prof. $(+1 \mathrm{Y})$

$0.010^{* * * *}$

$-0.537 * * *$

$-0.537 * \cdots *$
$(-3.44)$

$(-3.95)$

Yes

Yes

Other Controls

Industry FE

Credit Rating x Time FE

Loan Purpose FE

Time Period

Yes

Yes

Observations

1992-2014

Adjusted R ${ }^{2}$

1,632

0.335

European Facilities 404

Yes

Yes

Yes

Yes

1992-2014

1,410

0.162

404
Junk

(3) (4) $\Delta$ Rating $(+1 \mathrm{Y})$

$-0.119 \quad 0.000$

(-1.13) (0.24)

Yes Yes

Yes Yes

Yes Yes

Yes Yes

1992-2014 1992-2014

$3,731 \quad 3,833$

$0.238 \quad 0.111$

$270 \quad 300$

Panel B: Controlling for ex-post performance in the term loan spread regressions

\begin{tabular}{|c|c|c|c|c|}
\hline \multirow[b]{4}{*}{ Variable } & \multicolumn{4}{|c|}{ Term loans } \\
\hline & \multicolumn{2}{|c|}{ I-Grade } & \multicolumn{2}{|c|}{ Junk } \\
\hline & (1) & (2) & (3) & (4) \\
\hline & AISD & AISD & AISD & AISD \\
\hline \multirow{2}{*}{ Europe $1992-2002(0 / 1)$} & $-85.95 * * *$ & $-69.69 * * *$ & $-38.53^{*}$ & -33.73 \\
\hline & $(-4.82)$ & $(-4.06)$ & $(-1.72)$ & $(-1.41)$ \\
\hline \multirow[t]{2}{*}{ Europe 2003 - $2007(0 / 1)$} & -21.43 & -4.62 & 9.13 & 5.84 \\
\hline & $(-1.27)$ & $(-0.30)$ & $(0.67)$ & $(0.39)$ \\
\hline \multirow[t]{2}{*}{ Europe $2008-2010(0 / 1)$} & $-54.11 * * *$ & $-38.88^{*}$ & $-73.32 * * *$ & $-66.58 * * *$ \\
\hline & $(-2.86)$ & $(-1.95)$ & $(-2.95)$ & $(-2.92)$ \\
\hline \multirow[t]{2}{*}{ Europe 2011 - 2014 (0/1) } & $99.34 * * *$ & $96.55 * * *$ & $35.75 * *$ & $50.42 * * *$ \\
\hline & (4.09) & $(3.87)$ & $(2.17)$ & $(3.07)$ \\
\hline \multirow[t]{2}{*}{$\Delta$ Rating $(+1 \mathrm{Y})$} & & $19.77 * * *$ & & $35.37 * * *$ \\
\hline & & $(7.49)$ & & $(11.34)$ \\
\hline Other Controls & Yes & Yes & Yes & Yes \\
\hline Industry FE & Yes & Yes & Yes & Yes \\
\hline Credit Rating $x$ Time FE & Yes & Yes & Yes & Yes \\
\hline Loan Purpose FE & Yes & Yes & Yes & Yes \\
\hline Observations & 1,714 & 1,632 & 4,209 & 3,731 \\
\hline Adjusted $\mathrm{R}^{2}$ & 0.49 & 0.52 & 0.43 & 0.46 \\
\hline European Facilities & 429 & 404 & 321 & 270 \\
\hline
\end{tabular}




\section{Table 7}

\section{Institutional and foreign bank lending}

This table provides results of a linear regression of AISD on Europe (0/1), two interaction terms (Europe (0/1) * $\Delta$ Institutional lending high (0/1), Europe (0/1) * $\Delta$ Foreign lending high (0/1)), $\Delta$ Rating $(+1 Y)$, and control variables as reported in Table 2 using a sample of term loans. AInstitutional lending is defined as difference of the ratios of Term Loan B volume as percentage of total Term Loan volume in the U.S. versus Europe in a particular year. AInstitutional lending high (0/1) is a dummy variable which is either one or zero if the difference is either above or below its median. AForeign lending is defined as the difference of the ratios of foreign bank term lending volume as percentage of total Term Loan volume in the U.S. versus Europe in a particular year. AForeign lending high (0/1) is a dummy variable which is either one or zero if the difference is either above or below its median. The coefficients for the control variables and fixed effects are not shown for brevity. A variable definition is provided in Appendix A. We report t-values based on two-way robust standard errors clustered at the borrowing firm and year in parentheses. $* * *, * *, *$ denote significance at the 1,5 and $10 \%$ level, respectively.

\begin{tabular}{|c|c|c|c|c|c|c|}
\hline \multirow[b]{4}{*}{ Variable } & \multicolumn{6}{|c|}{ Term loans } \\
\hline & \multicolumn{3}{|c|}{ I-Grade } & \multicolumn{3}{|c|}{ Junk } \\
\hline & (1) & (2) & (3) & (4) & $(5)$ & (6) \\
\hline & AISD & AISD & AISD & AISD & AISD & AISD \\
\hline \multirow[t]{2}{*}{ Europe $(0 / 1)$} & 8.83 & $-66.25 * * *$ & $-51.48 *$ & $-58.92 * * *$ & -32.98 & $-73.33 * * *$ \\
\hline & $(0.23)$ & $(-8.94)$ & $(-1.96)$ & $(-3.85)$ & $(-1.40)$ & $(-2.83)$ \\
\hline \multirow[t]{2}{*}{ Europe $(0 / 1) * \Delta$ Institutional lending high $(0 / 1)$} & -11.87 & & -26.73 & $80.80 * * *$ & & $78.41^{* * *}$ \\
\hline & $(-0.25)$ & & $(-0.63)$ & $(3.16)$ & & (3.09) \\
\hline \multirow[t]{2}{*}{ Europe $(0 / 1) * \Delta$ Foreign lending high $(0 / 1)$} & & $86.25 * * *$ & $91.91 * * *$ & & 36.03 & 18.79 \\
\hline & & $(3.53)$ & $(3.37)$ & & $(1.13)$ & $(0.75)$ \\
\hline \multirow[t]{2}{*}{$\Delta$ Rating $(+1 \mathrm{Y})$} & $20.52 * * *$ & $20.59 * * *$ & $20.80 * * *$ & $34.96 * * *$ & $35.37 * * *$ & $34.97 * * *$ \\
\hline & $(4.49)$ & $(4.51)$ & $(4.53)$ & $(7.90)$ & $(8.14)$ & $(7.91)$ \\
\hline Other Controls & Yes & Yes & Yes & Yes & Yes & Yes \\
\hline Industry FE & Yes & Yes & Yes & Yes & Yes & Yes \\
\hline Credit Rating x Time FE & Yes & Yes & Yes & Yes & Yes & Yes \\
\hline Loan Purpose FE & Yes & Yes & Yes & Yes & Yes & Yes \\
\hline Time Period & $1992-2014$ & $1992-2014$ & $1992-2014$ & $1992-2014$ & $1992-2014$ & 1992-2014 \\
\hline Observations & 1,632 & 1,632 & 1,632 & 3,731 & 3,731 & 3,731 \\
\hline Adjusted R² & 0.50 & 0.51 & 0.51 & 0.46 & 0.46 & 0.46 \\
\hline European Facilities & 404 & 404 & 404 & 270 & 270 & 270 \\
\hline
\end{tabular}




\section{General}

Revolver (0/1)

Term Loan (0/1)

Dealscan

Dealscan

Other Loan $(0 / 1)$

Term B (0/1)

Purpose: Takeover $(0 / 1)$

Purpose: Ship, Plane, or SPV Finance (0/1)

Purpose: Project Finance (0/1)

Purpose: CP Backup (0/1)

Purpose: General Corporate (0/1)

Purpose: Other $(0 / 1)$

$\ln$ (\# Lenders)

Syndicate HHI

\section{Price Terms}

AISD

\section{AISU}

Spread

Facility Fee

Commitment Fee

Upfront Fee (UF)

Utilization fee (UTF)

Cancellation fee (CAF)

Usage Weighted Spread (UWS)

Total Cost of Borrowing (TCB)

\section{Non-Price Terms}

Facility Amoun

Maturity 1-3yr (0/1)

Maturity 3-6yr (0/1)

Maturity > 6yr $(0 / 1)$

Maturity

Secured (0/1)

Borrower characteristics

Europe (0/1)

Rating: AAA...B

\section{$\Delta$ Rating}

$\Delta$ Prof.

Stock Return Volatility

Book Equity Volatility

Cash \& STI Volatility

Total Assets

Leverage

Profitability

MTB

\section{Return variables}

Equity return

Index return

Excess return

\section{Loan supply variables}

$\Delta$ Institutional lending

$\Delta$ Institutional lending high $(0 / 1)$

$\Delta$ Foreign lending

$\Delta$ Foreign lending high $(0 / 1)$

Dealscan

Dealscan

Dealscan

Dealscan

Dealscan

Dealscan

Dealscan

Dealscan

Dealscan

Dealscan

Dealscan

Dealscan

Dealscan

Dealscan

Dealscan

Dealscan

Dealscan

Dealscan

Dealscan

Dealscan

Dealscan

Dealscan

Dealscan

Dealscan

Dealscan

Dealscan

Dealscan

S\&P

S\&P

-stream

Dealscan

Dealscan

Dealscan

Dealscan
Appendix A

Explanation of Variables

\section{Description}

Loans with type "Revolver/Line < 1 Yr.", "Revolver/Line >= 1 Yr.", "364-Day Facility", "Limited Line" or "Revolver/Term Loan" as indicated in the facility table in Dealscan.

Loans with type "Term Loan", "Term Loan A"-“Term Loan H" or "Delay Draw Term Loan" as indicated in the facility table in Dealscan.

Compustat

CRSP/Data

Compustat

Compustat

Compustat

Compustat

Compustat

Compustat

Datastream

Datastream

Datastream

Loans that are not classified as either term loans or revolver.

Loans with type "Term Loan B" to "Tern Loan H".

Loans with purpose "Takeover" as indicated in the facility table in Dealscan.

Loans with purpose "Aircraft finance" or "Ship finance" as indicated in the facility table in Dealscan.

Loans with purpose "Proj. finance" as indicated in the facility table in Dealscan

Loans with purpose "CP backup" as indicated in the facility table in Dealscan.

Loans with purpose "Corp. purposes" as indicated in the facility table in Dealscan.

Loans with purpose "Other" as indicated in the facility table in Dealscan.

Natural logarithm of the number of lenders.

Sum of the squared loan shares.

All-In-Spread-Drawn, defined as the sum of the spread over LIBOR or EURIBOR plus the facility fee.

All-In-Spread-Undrawn, defined as the sum of the facility fee and the commitment fee.

Spread over LIBOR, paid on drawn amounts on credit lines

Fee paid on the entire committed amount, regardless of usage.

Fee paid on the unused amount of loan commitments.

Fee paid upon completion of a syndicated loan.

Fee paid on the entire drawn amount once a certain usage threshold has been exceeded

Fee paid if the syndicated loan is cancelled before maturity

Weighted average of AISD and AISU.

Total cost of borrowing taking into account the spread, the facility fee, the commitment fee, the letter of credit fee, the utilization fee, the cancellation fee and the upfront fee

Facility amount in USD $\mathrm{mn}$ as indicated in the field FacilityAmt in the facility table in Dealscan.

A dummy variable, which equals one if the loan maturity is between 1 and 3 years, and zero otherwise.

A dummy variable, which equals one if the loan maturity is between 3 and 6 years, and zero otherwise.

A dummy variable, which equals one if the loan maturity larger than 6 years, and zero otherwise.

Loan maturity in months.

Indicates whether the loan is secured by collateral.

A dummy variable, which equals one if the borrower is a European firm and zero otherwise.

A dummy variable, which equals one if the borrower has an S\&P rating of AAA ... B at the time of the loan issue.

Change in credit rating notches.

Change in ratio of EBITDA to sales.

Standard deviation of firms' weekly stock returns for each calendar year, annualized by multiplying by $100 x \sqrt{52}$

Standard deviation of the ratio of borrowers' quarterly book equity to assets ratio (measured over the last 8 fiscal quarters).

Standard deviation of the ratio of borrowers' quarterly cash and short-term investment to assets (measured over the last 8 fiscal quarters).

Total assets in USD mn.

Ratio of book value of total debt to the book value of assets.

Ratio of EBITDA to sales.

Ratio of (book value of assets - book value of equity + market value of equity) to book value of assets.

Realized equity return over the prior 12 months (i.e., for regressions using yearly accounting data, the equity return in the 12 months prior to the fiscal year end date).

Realized stock index return of each country over the prior 12 months.

Equity Return minus Index Return.

Difference of the ratios of institutional term loan volume as percentage of total term loan volume in the U.S. versus Europe in a particular year.

Equal to 1 if the AInstitutional lending is above the median and 0 if it is below.

Difference of the ratios of foreign bank term lending volume as percentage of total term loan

volume in the U.S. versus Europe in a particular year.

Equal to 1 if the $\Delta$ Foreign lending is above the median and 0 if it is below. 


\section{Appendix B \\ Fees in the U.S. and the European Loan Market}

\section{B.I. Descriptive Statistics}

This table provides summary statistics for loan price terms separately for the U.S. and the European market. Panel A reports statistics for borrowers that have an investment grade rating at the time of the loan issue. Panel B reports statistics for borrowers that have a junk rating at the time of the loan issue. For variable definitions see Appendix A.

\begin{tabular}{|c|c|c|c|c|}
\hline \multirow[b]{3}{*}{ Variable } & \multicolumn{4}{|c|}{ Revolver } \\
\hline & \multicolumn{2}{|c|}{ U.S. Market } & \multicolumn{2}{|c|}{ European Market } \\
\hline & Mean & Observations & Mean & Observations \\
\hline \multicolumn{5}{|c|}{ Panel A: Investment Grade } \\
\hline$\overline{\text { AISD }}$ & 81.51 & 7,460 & 63.04 & 595 \\
\hline AISU & 15.69 & 7,460 & 21.23 & 595 \\
\hline Commitment Fee & 22.84 & 2,107 & 22.02 & 557 \\
\hline Facility Fee & 12.67 & 5,427 & 10.30 & 42 \\
\hline Utilization Fee & 11.28 & 2,207 & 8.00 & 300 \\
\hline Cancellation Fee & 126.39 & 18 & \#NA & \#NA \\
\hline Upfront Fee & 41.82 & 6,700 & 53.84 & 547 \\
\hline \multicolumn{5}{|c|}{ Panel B: Junk Grades } \\
\hline AISD & 214.64 & 4,432 & 199.16 & 119 \\
\hline AISU & 41.82 & 4,432 & 58.11 & 119 \\
\hline Commitment Fee & 42.84 & 3,981 & 58.58 & 113 \\
\hline Facility Fee & 29.44 & 507 & 57.81 & 8 \\
\hline Utilization Fee & 20.56 & 94 & 17.00 & 20 \\
\hline Cancellation Fee & 143.91 & 180 & 200.00 & 2 \\
\hline Upfront Fee & 52.53 & 4,261 & 58.89 & 113 \\
\hline
\end{tabular}




\section{B.II. Total Cost of Borrowing Definition}

$\mathrm{TCB}=\quad$ Upfront Fee / Loan Maturity in Years

+ (1-PDD) $\mathrm{x}$ (Facility Fee + Commitment Fee)

+ PDD x (Facility Fee + Spread $)$

+ PDD x Prob(Utilization>UtilizationThreshhold | Usage > 0) x Utilization Fee

+ Prob(Cancellation) $x$ Cancellation Fee

The first term annualizes the one-time upfront fee using the contractual maturity of the loan. Using the contractual maturity provides a conservative estimate of the annualized impact of the upfront fee on the total cost of borrowing, given that a large fraction of loans are refinanced prior to the contractual maturity. The second and third terms are a weighted average of the AISU (annual facility fee plus annual commitment fee) and the AISD (annual facility fee plus annual spread). The fourth term adds the annual utilization fee a borrower has to pay if usage exceeds a certain threshold, usually either $33 \%$ or $50 \%$ of the credit limit. The utilization fee has to be paid on the whole used amount of the credit line and not just on the utilization part above the threshold. Finally, the last term reflects the cost of cancellation weighted by the annual probability that a cancellation. Following BSS (2016), we predict PDD, Prob(Utilization>UtilizationThreshhold |Usage > 0), and Prob(Cancellation). ${ }^{43}$

BSS (2016) report, that the only fee type with an inaccurate coverage of fees in the Dealscan database is the upfront fee. In the U.S. over $80 \%$ of loan contracts contain an upfront fee, while this fraction is significantly lower in the Dealscan database. ${ }^{44}$ However, BSS (2016) also report that the information on the upfront fee is accurate if it is reported in Dealscan. We follow BSS (2016) and deal with this issue by predicting the upfront fee if it is missing in Dealscan. ${ }^{45}$

\footnotetext{
43 See BSS (2016), Online Appendix, http://www.tobias-berg.com/index.php/dont-ignore-the-fees/.

44 See BSS (2016), who compare SEC filings to DealScan and find this discrepancy.

45 See BSS (2016), Online Appendix, http://www.tobias-berg.com/index.php/dont-ignore-the-fees/.
} 


\section{B.III. AISD vs. TCB Decomposition}

This table provides results of a linear regression of price terms on European market dummy and control variables. For variable definitions see Appendix A. Fixed effects for loan purpose, one-digit SIC code, and borrower credit rating $\mathrm{x}$ year as well as other loan characteristics are included but not shown. We report t-values based on standard errors clustered at the borrowing firm in parentheses. $* * *, * * *$ denote significance at the 1 , 5 and $10 \%$ level, respectively.

\begin{tabular}{|c|c|c|c|c|c|}
\hline Sample & Revolver & Revolver & Revolver & Revolver & Revolver \\
\hline & (1) & $(2)$ & (3) & (4) & $(5)$ \\
\hline Variable & $\begin{array}{l}\text { TCB/ } \\
\text { AISD }\end{array}$ & $\begin{array}{l}\text { AISU/ } \\
\text { AISD }\end{array}$ & $\begin{array}{c}\text { UF/ } \\
\text { AISD }\end{array}$ & $\begin{array}{l}\text { UTF/ } \\
\text { AISD }\end{array}$ & $\begin{array}{l}\text { CAF/ } \\
\text { AISD }\end{array}$ \\
\hline Europe $(0 / 1)$ & $\begin{array}{c}0.21 * * * \\
(7.86)\end{array}$ & $\begin{array}{c}0.13 * * * * \\
(17.08)\end{array}$ & $\begin{array}{c}0.43 * * * \\
(9.27)\end{array}$ & $\begin{array}{c}0.01 \\
(0.80)\end{array}$ & $\begin{array}{c}0.00 \\
(0.30)\end{array}$ \\
\hline Other Controls & Yes & Yes & Yes & Yes & Yes \\
\hline Industry FE & Yes & Yes & Yes & Yes & Yes \\
\hline Credit Rating FE x Time FE & Yes & Yes & Yes & Yes & Yes \\
\hline Loan Purpose FE & Yes & Yes & Yes & Yes & Yes \\
\hline Time Period & $1992-2014$ & $1992-2014$ & 1992-2014 & 1992-2014 & 1992-2014 \\
\hline Observations & 11,527 & 12,600 & 11,620 & 12,600 & 12,600 \\
\hline Adjusted R² & 0.59 & 0.36 & 0.61 & 0.27 & 0.10 \\
\hline
\end{tabular}

Table B.III. reports the results of multivariate regressions of the TCB components on a European-dummy and covariates associated with the riskiness of loans and borrowers to analyze, which components explain the difference between TBC and AISD. Column 2 shows that the AISU is significantly higher for European loans also in a multivariate analysis (13\% with a t-stat of 17). 